ETHNIC DISCRIMINATION IN THE RENTAL HOUSING MARKET: AN EXPERIMENT IN NEW CALEDONIA

MATHIEU Bunel, SAMUEl GorohounA, YANNICK L'HorTy, PASCALE PETIT, CATHERINE RIS

TEPP - Institute for Labor Studies and Public Policies TEPP - Travail, Emploi et Politiques Publiques - FR CNRS 3435 
ISSN 2110-5472 


\title{
Ethnic Discrimination in the Rental Housing Market: An Experiment in New Caledonia
}

\author{
Mathieu BunEL ${ }^{1}$, Samuel GoroHOUnA ${ }^{2}$, Yannick L'HORTY ${ }^{3}$, ${\text { Pascale } \text { PETIT }^{4} \text {, Catherine RIS }}^{5}$
}

\begin{abstract}
This study focuses on the links between ethnic discrimination, housing discrimination, and the ethnic composition of neighborhoods at a specific spatial level, that of the city quarter. Our goal is to determine whether discrimination exacerbates residential segregation. We measure discrimination and access to housing in Greater Nouméa, the capital of New Caledonia, by ethnic background, distinguishing between the people of Kanak (the indigenous people) and those of European descent. Between October 2015 and February 2016, four applicants individually responded to 342 real estate rental ads, made a total of 1,368 responses. Two of the applicants made their Kanak origin known through their surnames, while two others similarly made their European origin known. In each pairing, an applicant signaled financial and professional stability by explicitly indicating that he was a civil servant. A particularity of the study was to analyze this data statistically by crossing it with the ethnic distribution of neighborhoods. Severe discrimination regarding access to private rental housing for Kanak applicants in all neighborhoods was found. Signaling stability strongly reduced discrimination against Kanak applicants. This discrimination is linked to the behavior of landlords and, to a lesser extent, to the actions of real estate agencies. The difficulties accessing housing are solely due to discrimination linked to the social precariousness of Kanaks in neighborhoods where Kanaks are most represented. They are also linked to ethnic discrimination against Kanaks in neighborhoods dominated by Europeans. Housing providers thus play an active role in residential segregation.
\end{abstract}

Keywords: Discrimination; Rental Market; Field experiment; New Caledonia JEL Classification: J15 R23 C93

\footnotetext{
${ }^{1}$ Mathieu BunEL, Université de la Nouvelle-Calédonie, LARJE (EA 3329) TEPP-CNRS (FR 3435), mathieu.bunel@univ-nc.nc

${ }^{2}$ Samuel GoroHOUNA, Université de la Nouvelle-Calédonie, LARJE (EA 3329), samuel.gorohouna@univ-nc.nc

${ }^{3}$ Yannick L'HORTY, Université Paris-Est, ERUDITE (EA 437), TEPP-CNRS (FR 3435), UPEC, UPEM, F-77454 Marne-La-Vallée France, yannick.lhorty@u-pem.fr .

${ }^{4}$ Pascale PETIT, Université Paris-Est, ERUDITE (EA 437), TEPP-CNRS (FR 3435), UPEC, UPEM, F77454 Marne-La-Vallée France. pascale.petit@u-pem.fr.

${ }^{5}$ Catherine RIS, Université de la Nouvelle-Calédonie, LARJE (EA 3329), catherine.ris@ univ-nc.nc
}

\footnotetext{
This research was supported by the The French National Research Agency - Grant DALTON ANR-15CE28-0004) and by the University of New-Caledonia. We are grateful to Tuamanaia FOIMAPAFISI for her assistance.
} 


\section{Introduction}

Works on urban segregation generally pay little attention to the issue of discrimination in terms of access to housing. However, while urban segregation is often a consequence of residential choices of populations, segregation is problematic when it is an outcome of housing market discrimination. Understanding the processes of discrimination in the housing market is useful both to analyze the determinants of spatial fractures that organize the territorial separation of social groups and also to define the most relevant public policies. ${ }^{6}$

Discrimination in terms of access to housing has been widely studied in the United States and more recently in various European countries and beyond. ${ }^{7}$ All works highlight that religious or ethnic minorities are victims of differences in treatment by the real estate market. Overall, applicants from these minorities are less frequently contacted and the number and quality of properties presented to them is lower.

Research indicates that the extent of discrimination in the housing market varies according to time and place. It can depend on the characteristics of the lessor, the type of property being rented, the neighborhood where the property is located, and the integration and/or economic stability signal transmitted by the applicant. However, as of yet, little work has focused on the spatialized aspect of discrimination in terms of access to housing by studying the role, in a local context, played by the real estate market.

Is there a link between the ethnic composition of a particular neighborhood and discrimination and access to housing on the basis of origin? Do lessors in the most segregated neighborhoods welcome minority applicants? If there is a link between the ethnic composition of a neighborhood and who lessors select? How should this link be interpreted?

In the United States, the first studies undertaken that took into account the ethnic environment at a disaggregated level are those by Yinger (1986), Page (1995), and Roychoudhury et al. (1996). Since then, Ondrich et al. (2003), followed by Hanson and Santas (2014), using larger samples, have clarified the relationship between the proportion of white people in a neighborhood and the extent of discrimination. The results obtained by

\footnotetext{
${ }^{6}$ Kain (1968) "The means by which racial segregation in housing has been maintained are amply documented. They are both legal and extra-legal; for example: racial covenants; racial zoning; violence or threats of violence; preemptive purchase; various petty harassments; implicit or explicit collusion by realtors, banks, mortgage lenders and other lending agencies."

${ }^{7}$ For the United States, see in particular publications by Yinger (1986), Choi et al. (2005), Page (1995), Choi et al. (2005), Ondrich et al. (2003), Hanson and Hawley (2011 and 2014); for Sweden, those by Ahmed et al. (2008 and 2010), Bengtsson et al. (2012), and Carlsson and Eriksson (2014); for France Bonnet et al. (2015); for Spain, the publication by Bosch et al. (2010); for Italy, the publication by Baldini and Federici (2011); for Greece, the publication by Drydakis (2011); for Belgium, publications by Heylen et al. (2015a, 2015b); for Australia, the publications by Nelson et al. (2015) and Galster et al. (2016); and for India, those by Thora et al. (2015) and Datta and Pathania (2016).
} 
these studies seem to indicate the existence of local threshold effects in the distribution of discrimination which leads to a tipping point on the effect of neighborhood composition on discrimination. Ondrich et al. (2003) demonstrate that discrimination is lower in neighborhoods where minorities are overrepresented, and Hanson and Santas (2014) show that discrimination is most prevalent in relatively mixed neighborhoods. In a compilation, Oh and Yinger (2015) emphasize that real estate agents play a central role in the racial and ethnic steering of applicants towards neighborhoods where their ethnic group is most represented.

In Europe, this neighborhood issue was addressed by Bengtsson et al. (2012) in the Greater Stockholm Area and by Baldini and Federici (2011) in various Italian regions. In France, Acolin et al. (2016) found that there is more discrimination in areas with more immigrants. These results, which are based on highly aggregated data, show that the share of minorities in the surroundings of the offer tested increases in proportion to the extent of discrimination. However, these results remain tenuous because they do not take into account neighborhood tipping and modifiable areal unit 8 that must be identified and controlled.

In Australia, Galster et al. (2016) assessed whether variation in discriminatory incidences across agents, home seekers, dwellings, and neighborhoods in Sydney was similar to that previously observed in the U.S. and Western European markets. They found that differences in geographic context and in the circumstances surrounding the home seekers and the dwellings sought jointly contributed to the likelihood that Anglos will receive favorable treatment from agents.

In this study, we propose to explore the relationship between discrimination and access to housing and local environment based on an experimental measure of discrimination in housing in a French territory according to community of belonging. We use a signal of stability, which makes it possible to distinguish discrimination based on information from discriminations based on preferences. Moreover, we take into account the local socio-ethnic composition at a specific level, that of the city quarter.

From October 2015 to February 2016, we conducted an access to private rental housing test in the Greater Nouméa area (the main agglomeration of New Caledonia) using a discrimination test method for two ethnic groups: Kanaks and Europeans. These communities represent respectively $26 \%$ and $33 \%$ of the population in the area studied. ${ }^{9}$ The high level of segregation in the Nouméa agglomeration means that it is perfectly suited for studying the link between ethnic environment and discrimination. In the southern part of this agglomeration, the share of the Kanak population is only 5\%, whereas in the

\footnotetext{
${ }^{8}$ The modifiable areal unit problem (MAUP) is a source of statistical bias that can alter the results of statistical hypothesis tests. When point-based measures of spatial phenomena are aggregated into districts, the resulting summary values can be influenced by both the shape and scale of the aggregation unit.

${ }^{9}$ In New Caledonia as a whole, Kanaks and Europeans represent respectively $39 \%$ and $27 \%$ of the population.
} 
northern part of the agglomeration, which is only 10 kilometers away, this proportion reaches $50 \%$.

Moreover, as in this geographical area the two ethnic groups studied are non-minorities, it is possible to clearly distinguish two phenomena: applying for housing as an applicant from an ethnic minority and applying for housing in a neighborhood in which one's ethnic group is underrepresented.

Beyond this spatial dimension, our study protocol also identifies the origin of this discrimination by distinguishing between discrimination resulting from the preferences of the housing providers and that which stems from the social situation and stereotypes regarding tenants' ability to pay. To this end, two profiles for each community were created, i.e., those who sent a signal of financial stability and those who did not. Lastly, in line with the work by Zhao (2005), Zhao et al. (2006), Bosch et al. (2010), and Heylen and Van den Broeck (2016), our analysis clarifies the impact of real estate agents on the process of discrimination and steering of applicants.

The results show that there is strong discrimination regarding access to housing against Kanak applicants in all neighborhoods of the agglomeration of Nouméa. However, sending a stability signal greatly reduces discrimination against them. The most notable result is that the community environment where housing is being offered strongly affects the scale and especially the nature of the discrimination. In districts where Kanaks are most represented, the difficulties of access to housing are essentially linked to discrimination stemming from their social precariousness, while such difficulties are linked to ethnic discrimination against Kanaks in neighborhoods highly dominated by Europeans. Housing providers thus play an active role in residential segregation.

The structure of the article is as follows. The first section contextualizes the social environment of the Nouméa agglomeration. The second provides an overview of the literature on discrimination in terms of access to housing, focusing in particular on interactions between ethnic environments and the extent of discrimination. The third describes the method and construction of data. The fourth presents the results of testing and discusses the links between discrimination and urban segregation. 


\section{Segregation and the housing market in the Nouméa agglomeration}

Located in the Pacific, New Caledonia is a French territory that enjoys a special status of broad autonomy, which is very different from the other French overseas communities. This island territory is characterized by severe inequalities based on ethnic background. Despite a proactive and relatively old policy aimed at promoting a more equitable distribution of resources, opportunities, and powers between communities, i.e., the so-called rebalancing (rééquilibrage) policy pledged in the Matignon Agreements (1988) and strengthened by the Nouméa Agreements (1998), Kanaks, the indigenous people, remain socially disadvantaged (Gorohouna and Ris,. 2013). While these inequalities have tended to decline in recent years, they remain significant in many socio-economic areas. ${ }^{10}$ Table A3 in the annex provides, based on data from the 2014 census, the differences in average socio-professional status by community of membership for the chosen field in our study (men aged 25-55 from the south province). It appears that the proportion of unemployed Kanaks out of the job market is double that of Europeans and their unemployment rate is seven times higher. Among the jobs held by Kanaks, $16.9 \%$ have a fixed term contract; $70 \%$ have a permanent contract in the private sector; and $13.1 \%$ a permanent contract in the public sector. For Europeans, these percentages are respectively $9.8 \%, 58.7 \%$, and $31.9 \%$. In terms of socio-professional situations, the discrepancies are also very large, as only $14.9 \%$ of employed Kanaks hold managerial positions or are mid-level professionals, while $48.1 \%$ of Europeans fall into this category.

Beyond these inequalities, New Caledonia is also characterized by a high level of ethnic and social segregation, in particular in the Greater Nouméa agglomeration, which includes the four most populated municipalities of New Caledonia's south province: Nouméa, Mont Dore, Païta, and Dumbéa. Some $60 \%$ of the population and $73 \%$ of the jobs in the archipelago are concentrated in this area. The southern neighborhoods, predominantly European and residential where well-to-do populations are clustered, sharply contrast with the northern neighborhoods, which are predominantly Kanak, poorer, and sometimes trapped in a process of ghettoization ${ }^{11}$ (Pestana et al. 2014). To measure the degree of segregation, we applied the usual Duncan and Duncan index of dissimilarity for the two groups, European and Kanak, in the urban area of Nouméa. Based on the census and by using a division of 78 neighborhoods, we obtained an index of 50.8. That means one have to change of neighborhoods more than $50 \%$ of Kanak in order to produce a distribution that matches that of the European. According to Lichter, Parisi, and de Valk (2017), in the US the estimated segregation indexes

\footnotetext{
${ }^{10}$ According to the Institut de statistique de New Caledonia (New Caledonia Institute of Statistics, or ISEE ), the employment rate was $49 \%$ for Kanaks and $71 \%$ for non-Kanaks; unemployment according to the census was $27 \%$ for Kanaks as opposed to $10 \%$ for other natives; $5 \%$ of Kanaks have a higher education degree, as opposed to $28 \%$ of non-Kanaks; conversely, only $3 \%$ hold managerial positions and $16 \%$ are mid-level professionals, as opposed to respectively $7 \%$ and $24 \%$ for other natives.

11 This is especially the case for the Rivière Salée neighborhood.
} 
vary substantially across metropolitan areas (13) ranging from 32.8 to 54.5. In Europe, this index ranges from 19 to 31 for four capitals.

The agglomeration's housing stock can be described using census data. In 2014, Greater Nouméa had more than 60,000 housing units. Among them, 51\% were occupied by their owners, $26 \%$ by tenants of private housing, $18 \%$ by tenants of social housing, and $5 \%$ could be characterized as unplanned housing (slums). There are notable differences between the city of Nouméa and the other areas in the agglomeration. In the latter, nearly two-thirds of the population own their lodgings compared to two-fifths for Nouméa. Social housing is concentrated mainly in the neighborhoods of Nouméa and Dumbéa, where they represent $21 \%$ of the housing stock, as opposed to $8 \%$ in other areas. There are notable spatial differences in the city of Nouméa depending on the neighborhoods. The northern neighborhoods are characterized by a relatively high proportion of unsanitary housing 12 and social housing. ${ }^{13}$ Conversely, in the southern neighborhoods of the city, only a very small proportion of housing is social housing and rental housing is of very good quality and significantly more expensive. ${ }^{14}$

\section{Discrimination regarding access to housing and the ethnic environment: an overview of the literature}

The testing method most commonly used to measure both discrimination and access to housing and access to employment is also the method that is predominant in the international literature (Bertrand and Duflo 2017). In the United States, following the Fair Housing Act (1968), a great number of studies used this methodology to analyze discrimination and access to housing. A number of testing campaigns were carried out in more than 30 American agglomerations over several successive waves $(1977,1989,2000$, and 2012) under the auspices of the Department of Housing and Urban Development. Experimental evidence of discriminatory behavior against Black, Hispanic, Asian, and Native Americans minorities was found to be widely practiced (see Oh and Yinger 2015 for a recent overview of these studies). In European countries, these tests, although more recent, also exist and confirm the presence of ethnic discrimination. ${ }^{15}$ In France, Alcolin et al. (2017), after having tested 300 offers, found strong evidence of ethnic discrimination in the housing market, while Bonnet et al. (2015), from a telephone test responding to 250 real estate ads, showed that being of North African origin had no significant discriminatory effect when applicants first indicated that they lived in a deprived suburb.

\footnotetext{
${ }^{12}$ According to the IEOM (2008), 4.2\% of the housing units of the downtown neighborhoods are unsanitary; this rate reaches 9\% in the Vallée du Génie, Quartier Latin, Vallée du Tir, Nouville, and Presqu'île de Ducos neighborhoods.

${ }^{13}$ The Tina sur mer neighborhood located north of Nouméa is an exception.

${ }^{14}$ According to a 2007 study, prices per $\mathrm{m} 2$ of apartments available for rent are $50 \%$ higher in the southern neighborhoods of Nouméa than in the rest of the agglomeration (IEOM, 2008).

${ }^{15}$ See note 7 .
} 
Three variants of discrimination tests coexist: a test based solely on an item of correspondence (a request for information sent by e-mail); a test based on a telephone call; and a test involving the physical presence of potential tenants. ${ }^{16}$ Articles by Heckman (1998) and Heckman and Siegelman (1993) identified and discussed the limitations associated with this third method, several of which may also apply to the telephone method.

Overall, the objective of these three methods is to compare the success rates of fictitious applicants who are meant to be similar in all aspects with the exception of the characteristic tested. For each of the preceding methods, two variants may exist: the first aims to randomly select a single profile (Carpusor and Loges, 2006) for each offer tested, while the second is based on sending all profiles to the same ad (Ahmed and Hammarstedt 2008). The advantage of the first strategy is to reduce the risk of being detected, but its main disadvantage is that it does not control the effect of unobservable fixed variables on the response rate. The second strategy offers the opposite advantages and disadvantages.

The results obtained by these various studies converge to emphasize that ethnic and religious minorities are discriminated against in most of the countries and cities studied. However, these studies demonstrate, given their great heterogeneity, that differences in response rates to the same housing offer vary between 0 and 30 percentage points. This is why most recent studies attempt to characterize and explain the elements that affect these differences.

In order to identify the role played by statistical discrimination (as Arrow, 1973, did) a number of authors crossed the ethnic or religious signal with a signal suggesting a high social level (speaking in a standardized, formal manner), a high level of integration (mastery of the language), or greater employment stability (elevated professional status). Overall, regardless of its form, a signal of quality greatly reduces the extent of discrimination without completely eliminating it (Massey and Lundy, 2001; Ahmed et al. 2010; Bosch et al. 2010; Baldini and Federici 2011); Drydakis 2011).

The role played by real estate agencies is more ambiguous. According to a test conducted in Belgium by Heylen and Van den Broeck (2016) that measured the proportion of agencies agreeing to exclude applicants of foreign origin when renting housing, real estate agencies seem to be a major channel of their clients' discrimination. Previous results by Ahmed and Hammarstedt (2008) confirm this conclusion for Sweden. However, the findings of Carpusor and Loges (2006) for the city of Los Angeles, indicate that agencies do not discriminate more than private owners, while those of Bosch et al. (2010) regarding different Spanish cities demonstrate that agencies can in fact have a moderating influence in this regard. For Australia, Galster et al. (2016) investigated the relationship between discrimination and neighborhood crime and

\footnotetext{
16 Thorat et al. (2015) and Bosch et al. (2010) are among the few references to combine two approaches simultaneously. The former demonstrated that when fictitious applicants are sent by email, discrimination is stronger than when initial contact is made by telephone. The latter demonstrated that there are no differences between emailed applications and making contact by telephone.
} 
demonstrated that rental agents in Sydney, regardless of their ethnicity, exhibited the most variation in discriminatory behaviors when the dwellings they were trying to rent were located in neighborhoods classified by differences in safety and tenure; agents were substantially more likely to favor Anglos in neighborhoods that were more desirable. They found that discriminatory behavioral patterns for Anglo and non-Anglo agents often were diametrically opposite in their responses to identical contexts.

One point that is little explored is the link between discrimination and the local ethnic environment of the housing offer. The question is whether discrimination against a given population segment can be linked to the size of this group within the local populace. This is an important question to address in order to understand the urban segregation process and its persistence over time. If the populations targeted for discrimination are a local minority, discrimination in the real estate market amplifies and maintains the phenomena of urban segregation, whereas if the populations represent a majority, the opposite is the case.

The studies do not seem to come to clear conclusions regarding the United States. Works by Yinger (1986), conducted in the city of Boston, by Page (1995), in 25 American cities, and by Roychoudhury and Goodman (1996), in Detroit, directly or indirectly examined the link between ethnic environment and the extent of discrimination. However, due to the size of their samples and/or the small differences in existing ethnic distributions in the areas studied, these studies were limited to a pair of neighborhood categories or to considerations at the level of neighborhoods.

Using larger bases (about 2,000 housing offers), Ondrich et al. (2003), Hanson and Hawley (2011), and Hanson and Santas (2014) produced more sophisticated analyses. They studied the extent of discrimination against Blacks and Hispanics based on the proportion of white people in the neighborhood of the offer in dozens of areas. They showed a nonlinear relation between these two variables that vary according to the cities considered. An agglomeration effect and a neighborhood effect coexist and remain to be characterized.

To our knowledge, in Europe, four studies integrate this dimension: Baldini and Federici (2011) in their study of different Italian regions, Bengtsson et al. (2012) in the Stockholm area, Carlsson and Eriksson (2014) in various Swedish regions, Acolin et al. (2016) in various French regions. These four studies seem to indicate that discrimination is only significant in areas with a larger concentrated share of immigrants (the northern regions of Italy for the first, the suburbs of Stockholm for the second, metropolitan areas for the third, and the Northeast, Southeast and Paris regions for the fourth). However, their results need to be confirmed because they may be sensitive to a modifiable areal unit problem or a fixed effect.

The objective of this article is to provide an in-depth study of the relationship between ethnic discrimination and ethnic segregation of a given neighborhood based on a geographically limited area characterized by major differences in ethnic distribution. 


\section{Experimental protocol and data collection}

We conducted a test to determine access to a private housing unit for rent in Greater Nouméa. The protocol did not cover access to social housing, achieved through very specific circuits, or access to private homes, which are rare in this area. Data collection took place from October 2015 to February 2016. We tested all ads for apartments for rent in Greater Nouméa published on the reference site http://www.immobilier.nc/ which centralizes all real estate offers in New Caledonia. ${ }^{17}$

The applicants for rental housing were men making their Kanak or European origin known through their surnames and first names. The choice of the surnames and first names correspond to credible and realistic identities. They are among the most common first names for this age group and for the community to which they belong. Surnames unambiguously indicate that a person is of Kanak or European background. ${ }^{18}$ The order of the response of each type of applicant was randomly changed daily throughout the data collection period. The test consisted of sending short and interrogative emails in response to ads published with a view to requesting a housing unit visit. The following messages were sent:

\begin{tabular}{|l|}
\hline Dear Sir or Madam: \\
Your ad fits the requirement that I am seeking. I would like to \\
arrange a visit to see the apartment. What documents do you \\
require? \\
Thank you, \\
First Name and Surname (our translation)
\end{tabular}

These messages were deliberately short, being a first contact. Questions were asked in order to elicit a reaction from the recipient. The surname indicated the ethnicity of the applicant. A specific database was created, listing for each offer the date of publication; the

\footnotetext{
17 The internet is not the only channel through which housing offers are advertised. Other channels such as newspapers and social networks were not taken into account in this study. In addition, in the case of real estate agencies, we retained only one offer per agency.

${ }^{18}$ For European surnames, we used names that are among the most common in metropolitan France. For Kanak surnames, we used common names that identify the person as being a member of a tribe of the south province of New Caledonia, that is to say, in the province where Greater Nouméa is located. Note that New Caledonia is a small archipelago and that Kanak family names are very characteristic and well known. The Kanak names used for our test are relatively widespread and associated with the great tribes of Grand Noumea (mainly in Mont-Dore and Païta) in the South Province. We chose two Kanak names from the Greater Noumea tribes to forestall a potential reaction from landlords who would be less inclined to rent to members from remote tribes (especially those from the Northern provinces and the Loyalty Islands). The landlords' concern would be that extended families (family in the broad sense that it may include several clans or tribes) would come regularly to stay in the future rented accommodations because return trips to and from their homes can be costly. This is an argument often used when deciding not to rent to a Kanak family. Choosing names from adjacent tribes limited this possibility because the extended family would have fewer reasons to stay with the renters, as round trips from their homes can be made in less than an hour.
} 
geographical location; the rental price per month; the size of the unit, both in terms of the number of rooms and square meters; the gender and status of the landlord (real estate agencies or individuals) ; and finally the nature of the response provided to the applicant.

Certain sprawling and sparsely populated neighborhoods of Greater Nouméa were not sampled. In the end, 31 neighborhoods were tested, sometimes with a very low number of ads (Map 1). In the spatial exploitation of results, a regrouping of neighborhoods into three areas was carried out (Map 2):

- group 1: neighborhoods in which Kanaks are a small minority (fewer than $15 \%$ of residents), located in the south of Nouméa

- group 2: mixed neighborhoods, located in Nouméa, where Kanaks represent $15 \%$ to $25 \%$ of the population

- group 3: neighborhoods comprising more than 25\% of Kanaks, located in the north of Nouméa and in the areas of Païta, Dumbéa, and Mont-Dore, regardless of the percentage of Kanaks ${ }^{19}$

In total, 342 real estate ads were tested, including 118 in group 1 (34.5\%), 156 in group 2 (45.6\%), and 68 in group 3 (19.9\%).

Potential differences in the spatial treatment of applicants may come from statistical discrimination or discrimination based on preferences. In order to identify these two sources of discrimination, as was done by Massey and Lundy (2001), Ahmed et al. (2010), Bosh et al. (2010), Baldini and Federici (2011), and Drydakis (2011), Galster et al. (2016), we crossed the ethnicity signal with a signal concerning the financial and professional stability of the applicant.

The following sentence was added to certain messages sent by our fictitious applicants: "I am a civil servant and I have just moved to Nouméa." This unambiguously signaled employment stability and on average a higher salary, given the indexation policy that exists in this area. ${ }^{20}$

As such, four rental applicant profiles were created (A-European, B-European civil servant, CKanak, D-Kanak civil servant). In the end, our base contained 1,368 responses to 342 real estate ads $(4 \times 342)$.

We chose to send the four messages in response to each ad to ensure that each of the fictitious individuals was confronted with the same characteristics of the agents (observable and unobservable). In this way, we could compare their chances of success for the same providers. If

\footnotetext{
${ }^{19}$ Ethnic disparities by neighborhood in the areas of Païta, Dumbéa, and Mont-Dore, disparities that also exist but in a markedly less pronounced manner than in Nouméa, could not be taken into account because the housing offers in these areas were too low.

${ }^{20}$ The salaries of civil servants in the area considered are multiplied by 1.73 compared to the French metropolitan grid. According to ISEE data, in New Caledonia, civil servants have higher incomes on average than people working in the private sector.
} 
we randomly sent a single fictitious individual's response to each announcement, we would not be able to ensure that each candidate was confronted on average with the same characteristics of the landlords as the other three individuals, given the restricted size of testing samples.

Notice that this perfect control for all the characteristics of the landlords has as a counterpart which is a higher risk of detection, which had to be considered. We believe that we minimized this risk, as well as its possible impact, in the following way. First, we only responded to ads uploaded three days before and, in most cases uploaded on the same day. The most recent ads were the ones that received the most responses, all other things being equal. We therefore made the reasonable assumption that other applicants' requests would be interspersed between our four messages, especially since we allowed at least one hour to elapse between the two messages addressed to the same ad. Furthermore, the messages were not "identical" but "similar," that is to say in terms of substance and form they resembled each other, but notable elements of differentiation in terms of formulation were introduced. We also noted that the websites to which we responded to the ads encouraged interested people to contact the offeror through that channel to ask for additional information or to request a visit to the apartment. In other words, it is common for landlords to receive this type of solicitation when they are posting a rental announcement online.

However, there was a concern that these precautions might not totally avoid the risk of detection. It was then necessary to examine what the reactions of a potential landlord would be in case of detection. Since discrimination is punishable, the landlords who realizes that they are being tested have an interest in not discriminating, i.e., not responding to any of the four solicitations or, in contrast, to respond in a similar manner to the four solicitations. Keep in mind that the order in which the four messages were sent to the same ad was random. Overall, none of the four fictitious individuals could therefore be penalized more than the others when the landlords finally realized their mistake. Assuming that some providers detected our test, we would have to minimize the extent of discrimination in our data. This amounted to providing a low range of extent of discrimination. However, even under this hypothesis, we nonetheless showed significant discrimination. Overall high response rates and the fact that $45 \%$ of landlords responded positively to all four ads might suggest no detection at all.

By comparing the results obtained for each of these profiles, our protocol evaluated the effect of ethnic background, the employment stability conditional, the effect of stability conditional on ethnic background, as well as cross effects, which combined the two aspects (diagram 1).

Finally, we noted that among the ads tested $87 \%$ were published by individuals and $13 \%$ by real estate agencies. Testing ads placed both by individuals and by real estate agencies enabled us to determine whether potential discrimination was linked to the personal preferences of the real estate agents and lessors and/or the characteristics of the neighborhoods or even whether the agencies played an active role in steering applicants, all hypotheses that are widely discussed in the literature (Choi et al. 2005; Oh and Yinger 2015). 
Diagram 1. Evaluated effects

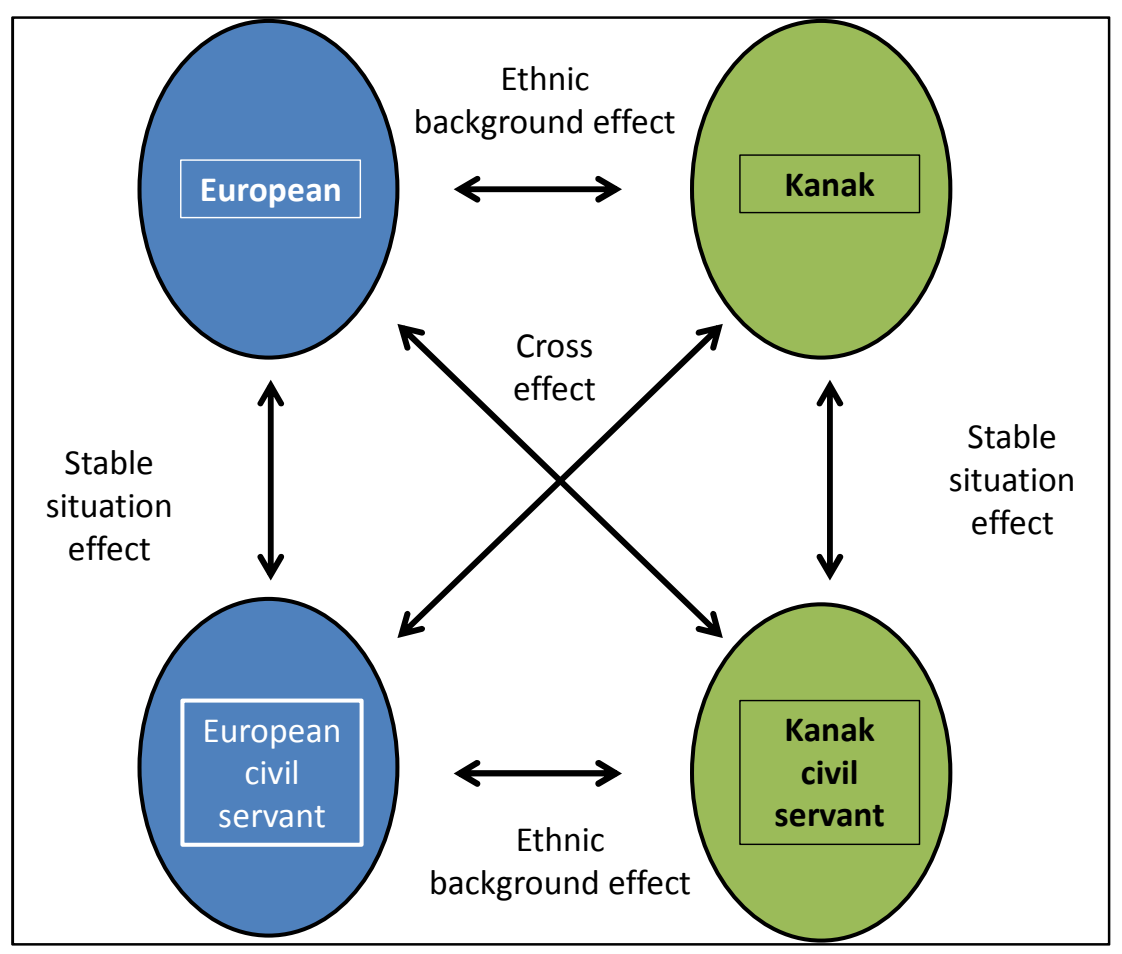


Map 1: Location and number of housing offers tested in Greater Nouméa

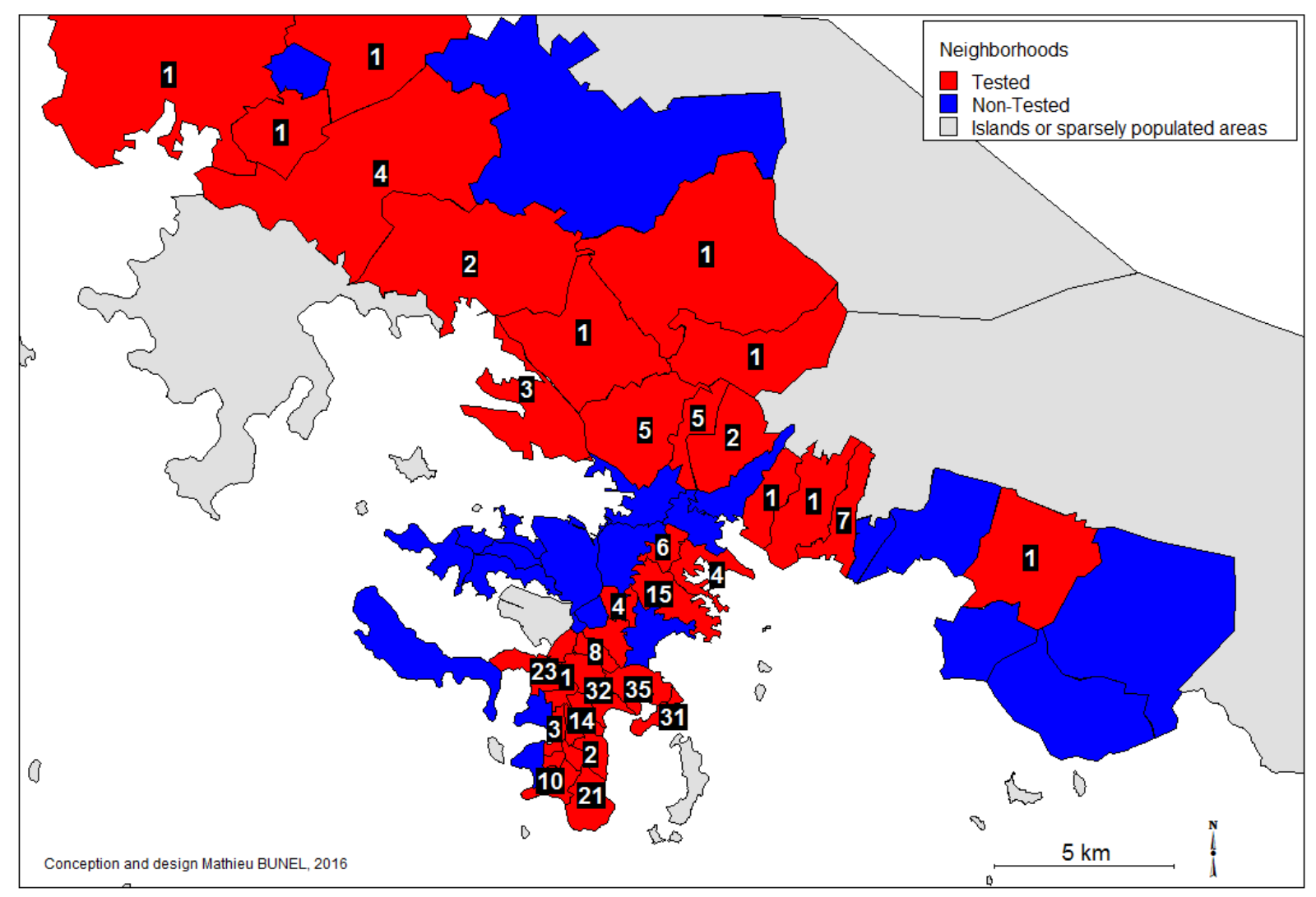




\section{Test results}

Of the 342 ads tested, 274 obtained at least one answer and in 258 cases these responses were positive. The response rate, calculated by dividing the number of positive responses by the total number of ads, exceeded $75 \% 21$ (Table 1 ).

Table 1. Distribution of the number of positive responses by offer

\begin{tabular}{lcc}
\hline $\begin{array}{l}\text { Number of positive responses by } \\
\text { offer }\end{array}$ & Number of cases \\
\hline None & 84 & $24.6 \%$ \\
1 and more & 258 & $75.4 \%$ \\
\hline Number of applicants contacted in the event of a positive response & \\
1 & 22 & $8.5 \%$ \\
2 & 36 & $14.0 \%$ \\
3 & 45 & $17.4 \%$ \\
4 & 155 & $60.1 \%$ \\
\hline
\end{tabular}

Source: DALTON database

We will first present the aggregated results for all of Greater Nouméa before presenting the results by neighborhood groups.

\section{Aggregated results}

The applicant who was most frequently contacted by lessors was the European applicant who signaled stability by mentioning that he was a civil servant (Table 2). He was contacted $67.5 \%$ of the time in response to his requests. Next was the European applicant who did not signal stability (65.2\%), followed by the Kanak civil servant applicant (63.5\%), and finally the Kanak applicant who did not signal stability $(52.0 \%)$. The latter was systematically the least often contacted, regardless of the total number of responses by the lessor. Based on these results, the European applicant who signaled stability sent out 14.8 applications to receive 10 positive responses, while the Kanak applicant who did not signal stability sent 19.2 applications.

\footnotetext{
21 The response rates per applicant were slightly higher in our study than in those conducted in the United States (Carlsson and Eriksson 2014), in Italy (Baldini and Federici 2011), in Sweden (Ahmed et al. 2010), in Spain (Bosch et al. 2010), or in Australia (Galster et al, 2016), which vary between 40\% and 70\%.
} 
Table 2. Non-null response rates by type of applicant

\begin{tabular}{|c|c|c|c|c|c|c|c|c|c|c|}
\hline \multirow[t]{3}{*}{ Type of applicant } & \multirow{2}{*}{\multicolumn{2}{|c|}{$\begin{array}{l}\text { Non-null } \\
\text { response rate }\end{array}$}} & \multicolumn{8}{|c|}{ Response rate as a condition of the total number of responses } \\
\hline & & & \multicolumn{2}{|c|}{1} & \multicolumn{2}{|r|}{2} & \multicolumn{2}{|c|}{3} & \multicolumn{2}{|c|}{ At least 1} \\
\hline & $\mathrm{N}$ & $\%$ & $\mathrm{~N}$ & $\%$ & $\mathrm{~N}$ & $\%$ & $\mathrm{~N}$ & $\%$ & $\mathrm{~N}$ & $\%$ \\
\hline European civil servant & 231 & $67.5 \%$ & 13 & $52.0 \%$ & 24 & $66.7 \%$ & 39 & $86.7 \%$ & 231 & $89.5 \%$ \\
\hline European & 223 & $65.2 \%$ & 3 & $12.0 \%$ & 26 & $72.2 \%$ & 39 & $86.7 \%$ & 223 & $86.4 \%$ \\
\hline Kanak civil servant & 217 & $63.5 \%$ & 5 & $20.0 \%$ & 17 & $47.2 \%$ & 40 & $88.9 \%$ & 217 & $84.1 \%$ \\
\hline Kanak & 178 & $52.0 \%$ & 1 & $4.0 \%$ & 5 & $13.9 \%$ & 17 & $37.8 \%$ & 178 & $69.0 \%$ \\
\hline Number of offers & \multicolumn{2}{|c|}{342} & \multicolumn{2}{|c|}{25} & \multicolumn{2}{|c|}{36} & \multicolumn{2}{|c|}{45} & \multicolumn{2}{|c|}{258} \\
\hline
\end{tabular}

Source: DALTON database

When comparing applicants with different statuses, discrepancies between the two European applicants were statistically insignificant, indicating that the stability signal of being a civil servant is not valued by lessors for a European applicant (Table 3 and Table 4). On the other hand, the difference between the two Kanak applicants was significant, indicating this time that the stability signal of being a civil servant is highly valued by a lessor when it comes to a Kanak applicant (an 11 point difference in this respect).

As a result of the bonus access, the status of the Kanak civil servant did not differ significantly from that of the two European applicants, at a threshold of 5\%. On the other hand, the difference between the European applicants and Kanaks of the same status, who either identified as civil servants or were without apparent status, was significant (10\% for civil servant applicants alone). These results suggest the coexistence of two sources of discrimination: information discrimination, or statistical discrimination, vis- à -vis the Kanak applicant who did not signal stability, as evidenced by the differences between the Europeans and the Kanaks, which dwindled sharply when the latter signaled employment stability, such as being a civil servant and discrimination based on preferences, of a lesser magnitude, revealed by the fact that significant differences existed between the European and Kanak civil servants (a discrepancy of 4 percentage points).

Thus, a Kanak who does not signal stability is the victim of double discrimination, being targeted for his or her ethnic background and because of real or presumed social precariousness. Taken together, the two elements result in a penalty of about 15 percentage points in the response rate upon initial contact with the lessor. Compared to the applicant of European origin, this corresponds in relative value to a total discrepancy of nearly $30 \%$, a very considerable figure indeed. 
Table 3. Gross rate of non-null responses for the same advertisements (in \%)

\begin{tabular}{lccccc}
\hline \multicolumn{1}{c}{ Type of applicant } & $\begin{array}{c}\text { Non-null } \\
\text { response rate }\end{array}$ & Standard deviation & Student T & $\begin{array}{c}\text { Confidence interval } \\
\text { of 90\% } \\
\text { Upper limit }\end{array}$ \\
\hline European civil servant & $67.5^{* * *}$ & 2.53 & 26.72 & 63.3 & 71.7 \\
European & $65.2^{* * *}$ & 2.58 & 25.27 & 61.0 & 69.4 \\
Kanak civil servant & $63.5^{* * *}$ & 2.57 & 24.65 & 59.2 & 67.7 \\
Kanak & $52.1^{* * *}$ & 2.66 & 19.55 & 47.7 & 56.4 \\
\hline Student statistics and confidence intervals calculated using the bootstrap method based on 10.000 replicates &
\end{tabular}

Student statistics and confidence intervals calculated using the bootstrap method based on 10,000 replicates

*** Significant at a threshold of $1 \%$

Source: DALTON database

Table 4. Differences in the success rates of fictitious applicants for the same offers according to the applicant's work situation and background (in \% points)

\begin{tabular}{|c|c|c|c|c|}
\hline \multirow{2}{*}{2 on 2 comparisons for the same offers } & \multirow{2}{*}{$\begin{array}{l}\text { Deviation } \\
\text { (in \% points) }\end{array}$} & \multirow{2}{*}{ Student } & \multicolumn{2}{|c|}{$\begin{array}{c}\text { Confidence interval } \\
\text { of } 90 \%\end{array}$} \\
\hline & & & $\begin{array}{l}\text { Lower } \\
\text { limit }\end{array}$ & $\begin{array}{l}\text { Upper } \\
\text { limit }\end{array}$ \\
\hline \multicolumn{5}{|c|}{ Effect of stability signal (reference applicant: no stability signal) } \\
\hline All & $6.9 * * *$ & 5.04 & 4.7 & 9.1 \\
\hline Europeans & 2.4 & 1.21 & 0.84 & 5.54 \\
\hline Kanak & $11.4^{* * *}$ & 5.52 & 8.01 & 14.78 \\
\hline \multicolumn{5}{|l|}{$\begin{array}{l}\text { Ethnic background signal effect } \\
\text { (European reference applicant) }\end{array}$} \\
\hline All & $-8.6^{* * *}$ & -5.00 & -11.4 & -5.8 \\
\hline Employment stability signal & $-4.1^{*}$ & -1.85 & -7.71 & -0.46 \\
\hline No stability signal & $-13.2 * * *$ & -5.75 & -16.95 & -9.42 \\
\hline \multicolumn{5}{|c|}{ Cross effect (European reference applicant with stable employment) } \\
\hline $\begin{array}{l}\text { Kanak whose work situation was not } \\
\text { disclosed }\end{array}$ & $-15.51 * * *$ & -6.55 & -19.39 & -11.62 \\
\hline
\end{tabular}

Student statistics and confidence intervals calculated using the bootstrap method based on 10,000 replicates

*** Significant at the 1\%, ** 5\%, * 10\% threshold

Source: DALTON database 
Table 5 Presents the detailed results of the tests and distinguishes between them according to the origin of the offers, whether they came from an individual or a real estate agency. Similar to Choi et al. (2005), Ahmed and Hammarstedt (2008), Bosch et al. (2010), and Heylen and Van den Broeck (2015), and contrary to Carpusor and Loges (2006), there are differences between private owners and agencies. Agencies respond more often to all applicants and discriminate less often (Table 5). ${ }^{22}$ Discrimination against Kanaks is more pronounced with an individual than a professional landlord (-4.7 vs.-1.5 and -14.1 vs. -9.0).

This is an interesting result because it invalidates the hypothesis that housing discrimination is essentially driven by the preferences of real estate agents. While we found real estate agents to be involved in the process of discrimination as regards such access, we are not in a position to determine whether they acted based on their own preferences or if they responded to requests expressed more or less explicitly by those whom they represented. Given the size of our sample, we were unable to explore this link any further.

\footnotetext{
${ }^{22}$ We also tested whether the gender of the lessor influences the response rate and level of discrimination. As with Ahmed et al. 2008, this dimension did not significantly affect the results.
} 
Table 5. Differences in the success rates of fictitious applicants for the same offers according to the applicant's work situation and background based on the status of the offerer (in \% points)

\begin{tabular}{|c|c|c|c|c|}
\hline \multirow[t]{2}{*}{2 on 2 comparisons for the same offers } & \multirow[t]{2}{*}{$\begin{array}{l}\text { Deviation } \\
\text { (in \% points) }\end{array}$} & \multirow[t]{2}{*}{ Student } & \multicolumn{2}{|c|}{$\begin{array}{c}\text { Confidence interval } \\
\text { of } 90 \%\end{array}$} \\
\hline & & & Lower limit & Upper limit \\
\hline \multicolumn{5}{|l|}{ Offers by agencies } \\
\hline \multicolumn{5}{|c|}{ Stability signal effect (reference applicant: no stability signal) } \\
\hline All & 6.1 & 1.31 & 1.5 & 13.7 \\
\hline Europeans & 3.1 & 0.83 & 3.0 & 9.1 \\
\hline Kanak & $10.5 * *$ & 2.01 & 1.9 & 19.1 \\
\hline \multicolumn{5}{|l|}{$\begin{array}{l}\text { Ethnic background signal effect } \\
\text { (European reference applicant) }\end{array}$} \\
\hline All & -5.3 & -1.18 & -12.6 & 2.0 \\
\hline Employment stability signal & -1.5 & -0.31 & -9.7 & 6.6 \\
\hline No stability signal & $-9.0+$ & -1.62 & -18.1 & 0.1 \\
\hline \multicolumn{5}{|c|}{ Cross effect (European reference applicant with stable employment) } \\
\hline Kanak whose work situation was not disclosed & $-12.0 * *$ & -2.07 & -21.5 & -2.5 \\
\hline \multicolumn{5}{|l|}{ Offers by individuals } \\
\hline \multicolumn{5}{|c|}{ Stability signal effect (reference applicants: no stability signal) } \\
\hline All & $4.5 * * *$ & 2.56 & 1.6 & 7.4 \\
\hline Europeans & 2.2 & 0.97 & 1.5 & 5.9 \\
\hline Kanak & $11.6 * * *$ & 5.22 & 8 & 15.2 \\
\hline \multicolumn{5}{|l|}{$\begin{array}{l}\text { Ethnic background signal effect } \\
\text { (European reference applicant) }\end{array}$} \\
\hline All & $-9.4 * * *$ & -5.09 & -12.5 & -6.4 \\
\hline Employment stability signal & $-4.7 *$ & -1.89 & -8.8 & -0.6 \\
\hline No stability signal & $-14.1 * * *$ & -5.61 & -18.3 & -10.0 \\
\hline \multicolumn{5}{|c|}{ Cross effect (European reference applicant with stable employment) } \\
\hline Kanak whose work situation was not disclosed & $-16.3 * * *$ & -6.24 & -20.5 & -12.0 \\
\hline
\end{tabular}

Student statistics and confidence intervals calculated using the bootstrap method based on 10,000 replicates

$* * *$ Significant at the $1 \%$, * 5\%, *10\% threshold + The p-value is 0.1023

Source: DALTON database 


\section{Disaggregated results by group of neighborhoods}

The high level of ethnic segregation in the Nouméa agglomeration makes it possible to identify the effect of socio-ethnic concentration of neighborhoods on the extent and nature of discrimination in the same area. Tables 6 and 7 present the results obtained for the three types of neighborhoods we selected: strongly segregated (group 1), segregated (group 2), slightly segregated (group 3).

The results obtained point to two elements: on one hand, there are fairly clear differences in treatment depending on the type of neighborhood and, on the other, this discrimination stems from different sources depending on the neighborhood. More specifically, we believe that statistical discrimination and discrimination based on preferences can be attributed differentially between neighborhoods.

In neighborhoods with the highest Kanak concentration, housing providers strongly value the stability signal from Kanak applicants who indicate that they are civil servants. The probability of being called back increases by 20.7 percentage points. Aside from this aspect, there are no statistically significant differences related to the ethnic community that housing-seekers belong to. The difficulties that Kanaks experience in accessing housing in these neighborhoods, which are very real, constitute statistical discrimination related to social and employment instability, perceived as excessive by providers.

In intermediate neighborhoods, we found evidence of statistical discrimination against Kanaks: an employment stability signal significantly increases their chances of accessing housing (by nine points). There is also evidence of ethnic discrimination in the narrow sense of the term: compared with European applicants, a Kanak's chances of obtaining housing drops by 11.6 points if they exhibit no sign of stability and by 5.8 points if they indicate that they are employed in the civil service.

Ethnic discrimination is most evident in neighborhoods with the fewest Kanak residents, i.e., below $15 \%$. Their chances compared to those of Europeans are reduced by 17.4 points if they show no signs of financial stability and by 6.7 points in the case of civil servants. In addition, there are similar levels of statistical discrimination in the southern neighborhoods of Nouméa. A stability signal increases a Kanak's chances in these areas by 11.6 points, similar to the neighborhoods mentioned above. 
Table 6. Raw rate of non-null responses to the same advertisements (in \%)

\begin{tabular}{|c|c|c|c|c|c|}
\hline \multirow{2}{*}{ Type of applicant } & \multirow{2}{*}{$\begin{array}{l}\text { Rate of non- } \\
\text { null responses }\end{array}$} & \multirow{2}{*}{$\begin{array}{l}\text { Standard } \\
\text { deviation }\end{array}$} & \multirow[t]{2}{*}{ Student T } & \multicolumn{2}{|c|}{$\begin{array}{c}\text { Confidence interval } \\
\text { of } 90 \%\end{array}$} \\
\hline & & & & Lower limit & Upper limit \\
\hline \multicolumn{6}{|c|}{ Neighborhoods with under 15\% Kanak residents (group 1) } \\
\hline European civil servant & $68.6^{* * *}$ & 4.31 & 15.93 & 61.5 & 75.7 \\
\hline European non civil servant & $69.5^{* * *}$ & 4.28 & 16.25 & 62.5 & 76.5 \\
\hline Kanak civil servant & $63.5^{* * *}$ & 4.41 & 14.41 & 56.3 & 70.8 \\
\hline Kanak non civil servant & $51.6 * * *$ & 4.66 & 11.09 & 44.0 & 59.3 \\
\hline \multicolumn{6}{|c|}{ Neighborhoods with $15 \%$ to $25 \%$ Kanak residents in Nouméa (group 2) } \\
\hline European civil servant & $68.6 * * *$ & 3.76 & 18.26 & 62.4 & 74.8 \\
\hline European non civil servant & $65.4 * * *$ & 3.76 & 17.37 & 59.2 & 71.6 \\
\hline Kanak civil servant & $62.8^{* * *}$ & 3.89 & 16.17 & 56.4 & 69.2 \\
\hline Kanak non civil servant & $53.8^{* * *}$ & 4.00 & 13.45 & 47.2 & 60.3 \\
\hline \multicolumn{6}{|c|}{ Neighborhoods with over $25 \%$ Kanak residents in and outside Nouméa (group 3) } \\
\hline European civil servant & $63.2 * * *$ & 5.9 & 10.8 & 53.5 & 72.8 \\
\hline European non civil servant & $57.4^{* * *}$ & 5.9 & 9.7 & 47.6 & 67.1 \\
\hline Kanak civil servant & $64.7^{* * *}$ & 5.8 & 11.2 & 55.1 & 74.2 \\
\hline Kanak non civil servant & $48.4^{* * *}$ & 6.1 & 7.9 & 38.4 & 58.5 \\
\hline
\end{tabular}

Student statistics and confidence intervals calculated using the bootstrap method based on 10,000 replicates

*** Significant at the threshold of $1 \%$, ** of $5 \%$, *f $10 \%$

Remark: The \% of Kanaks per neighborhood is drawn from Pestana et al. (2015) using 2009 ISEE census data

Source: DALTON database 
Table 7. Differences in the success rate of fictitious applicants responding to the same advertisements according to their work situation and background based on the ethnic environment of the housing location (in percentage points)

\begin{tabular}{|c|c|c|c|c|}
\hline \multirow{2}{*}{2 on 2 comparisons for the same offers } & \multirow{2}{*}{$\begin{array}{l}\text { Deviation } \\
\text { (in \% points) }\end{array}$} & \multirow[t]{2}{*}{ Student } & \multicolumn{2}{|c|}{$\begin{array}{c}\text { Confidence interval } \\
\text { of } 90 \%\end{array}$} \\
\hline & & & $\begin{array}{l}\text { Lower } \\
\text { limit }\end{array}$ & Upper limit \\
\hline \multicolumn{5}{|c|}{ Neighborhoods with under 15\% Kanak residents (group 1) } \\
\hline \multicolumn{5}{|c|}{ Stability signal effect (reference applicant: no stability signal) } \\
\hline All & 2.9 & 1.16 & -1.2 & 7.0 \\
\hline European & 0.9 & 0.24 & -5.0 & 6.7 \\
\hline Kanak & $11.6 * * *$ & 3.50 & 6.2 & 17.1 \\
\hline \multicolumn{5}{|c|}{ Ethnic background signal effect (European reference applicant) } \\
\hline All & $-12.0 * * *$ & -4.32 & -16.5 & -7.4 \\
\hline Employment stability signal & $-6.7^{*}$ & -1.72 & -13.1 & -0.3 \\
\hline No stability signal & $-17.4 * * *$ & -4.53 & -23.6 & -11.1 \\
\hline \multicolumn{5}{|c|}{ Cross effect (European reference applicant with stable employment) } \\
\hline Kanak whose work situation was not disclosed & $-18.2 * * *$ & -4.31 & -25.1 & -11.3 \\
\hline \multicolumn{5}{|c|}{ Neighborhoods with $15 \%$ to $25 \%$ Kanak residents in Nouméa (group 2) } \\
\hline \multicolumn{5}{|c|}{ Stability signal effect (reference applicant: no stability signal) } \\
\hline All & 3.2 & 1.28 & 0.9 & 7.3 \\
\hline European & 3.2 & 1.29 & 0.9 & 7.2 \\
\hline Kanak & $9.0^{* * *}$ & 2.80 & 3.7 & 14.3 \\
\hline \multicolumn{5}{|c|}{ Ethnic background signal effect (European reference applicant) } \\
\hline All & $-8.7 * * *$ & -3.42 & -12.8 & -4.5 \\
\hline Employment stability signal & $-5.8 *$ & -1.89 & -10.8 & -0.8 \\
\hline No stability signal & $-11.6^{* * *}$ & -3.34 & -17.2 & -5.9 \\
\hline \multicolumn{5}{|c|}{ Cross effect (European reference applicant with stable employment) } \\
\hline Kanak whose work situation was not disclosed & $-14.7^{* * *}$ & -4.23 & -20.5 & -9.0 \\
\hline \multicolumn{5}{|c|}{ Neighborhoods with over $25 \%$ Kanak residents in and outside Nouméa (group 3) } \\
\hline \multicolumn{5}{|c|}{ Stability signal effect (reference applicant: no stability signal) } \\
\hline All & $17.2^{* * *}$ & 2.21 & 4.5 & 30.0 \\
\hline European & 6.7 & 1.00 & -4.3 & 17.8 \\
\hline Kanak & $20.7^{* * *}$ & 2.78 & 8.5 & 32.9 \\
\hline \multicolumn{5}{|c|}{ Ethnic background signal effect (European reference applicant) } \\
\hline All & 0.0 & 0.00 & -10.6 & 10.6 \\
\hline Employment stability signal & 7.0 & 0.83 & -6.8 & 20.7 \\
\hline No stability signal & -6.9 & -1.01 & -18.0 & 4.3 \\
\hline \multicolumn{5}{|c|}{ Cross effect (European reference applicant with stable employment) } \\
\hline Kanak whose work situation was not disclosed & $-13.7^{*}$ & -1.69 & -27.0 & -0.4 \\
\hline
\end{tabular}




\section{Econometric confirmation}

Finally, Tables 8 and 9 present the results obtained using a random effects Probit model. This model estimates the probability of obtaining a positive response conditional on observed characteristics of offers by assuming that part of the variance of the error term is common to all tested offers.

The 0 model estimates the model without a characterization variable for offers. It confirms the existence of two sources of discrimination: income, with an estimated absence of stability signal (NON-STABLE) and ethnic background (KANAK) and the cross effect of NON-STABLE X Kanak obtained in previous tables. This effect exceeds in absolute value the stability effect, which indicates the coexistence of two sources of discrimination, based on preference and on information.

Model 1 adds a large number of control variables related to neighborhood of residence, apartment size, the gender of the lessor, and the nature of the lessor (individual or agency). The coefficients of the variables of interest hardly change in response to the addition of these numerous controls, thereby confirming the coexistence of two difficulties faced by Kanaks in matters of access to housing: the absence of stable income, on the one hand, and ethnic discrimination on the other.

It should be noted that for models 0 and 1 , the intra-class correlation is very important, i.e., 0.86 , meaning that $86 \%$ of the variance of the probability of any of the four fictitious applicants being contacted by the lessor was due to the behavior of the landlords.

The computation of the marginal effects associated with the employment stability signal effect and the ethnic signal effect obtained using model 2 confirms the aforementioned results (Table 9). In addition, when estimating these effects in relation to the three categories of neighborhoods, we obtain a non-significant effect for the ethnic signal in mixed neighborhoods (the coefficient of which is twice or three times lower), whereas in the two highly segregated neighborhoods it is significant and very negative. By contrast, the stability signal's importance in mixed neighborhoods is two-fold compared with segregated neighborhoods. In these areas, where rent cost is lower, landlords must expect a lesser degree of self-selection among tenants and accept a greater risk of default of payment on their part. This is why they are more sensitive to the financial stability signal. 
Table 8. Random effects Probit model

\begin{tabular}{|c|c|c|c|c|}
\hline \multirow[b]{2}{*}{ Location of the offer } & \multicolumn{2}{|c|}{ Model 0} & \multicolumn{2}{|c|}{ Model 1} \\
\hline & Coef. & std. & Coef. & std. \\
\hline Absence of stability signal (non-stable) & $-0.575 * *$ & 0.289 & $-0.574 * * *$ & 0.289 \\
\hline Kanak & -0.332 & 0.289 & -0.331 & 0.289 \\
\hline Non-stable $\times$ Kanak & $-1.157^{* * *}$ & 0.408 & $-1.156 * * *$ & 0.407 \\
\hline \multicolumn{5}{|l|}{ Characteristics of the offer } \\
\hline \multicolumn{5}{|l|}{ Ethnic environment of the housing location } \\
\hline Less than $15 \%$ (group 1) & & & -0.250 & 0.701 \\
\hline Between $15 \%$ and $25 \%$ in Nouméa (group 2) & & & Ref. & \\
\hline Over 25\% and outside Nouméa (group 3) & & & -0.169 & 0.822 \\
\hline \multicolumn{5}{|l|}{ Size of apartments (ref: F2-LOFT) } \\
\hline F1 & & & -0.331 & 0.924 \\
\hline F3 & & & $1.393 *$ & 0.764 \\
\hline F4-F5 & & & $1.723 *$ & 0.990 \\
\hline \multicolumn{5}{|l|}{ Characteristics of the lessor } \\
\hline Woman & & & 0.921 & 0.619 \\
\hline \multicolumn{5}{|l|}{ Type of lessor (ref: Agency) } \\
\hline Individuals & & & -0.596 & 0.805 \\
\hline \multicolumn{5}{|l|}{ Price per $m^{2}$} \\
\hline $\begin{array}{l}\text { Relation between the price per } \mathrm{m}^{2} \text { and the average price in this } \\
\text { neighborhood }\end{array}$ & & & -0.013 & 0.010 \\
\hline Game A & & & OUI & \\
\hline Constant & $2.272 * * *$ & 0.389 & $3.331 * * *$ & 1.768 \\
\hline Sigma & $4.828 * * *$ & 0.484 & $4.628 * * *$ & 0.470 \\
\hline Akaike information criterion & $1,217.0$ & & $1,217.2$ & \\
\hline Log-likelihood & -603.5 & & -594.6 & \\
\hline Pseudo-R2 & $4.8 \%$ & & $6.2 \%$ & \\
\hline
\end{tabular}

***Significant at the 1\%, ** 5\%, *10\% threshold

Source: DALTON database 
Table 9. Marginal effects from Model 1 for all neighborhoods and by neighborhood sector

\begin{tabular}{|c|c|c|c|c|c|}
\hline Type of neighborhoods & $\begin{array}{l}\text { Marginal } \\
\text { effect }\end{array}$ & $\begin{array}{l}\text { Standard } \\
\text { deviation }\end{array}$ & p-value & $\mathrm{N}$ & $\begin{array}{l}\text { Akaike } \\
\text { criterion }\end{array}$ \\
\hline \multicolumn{6}{|l|}{ All tested neighborhoods } \\
\hline Ethnic background signal (being Kanak) & $-0.086 * * *$ & 0.016 & 0.000 & 1,368 & $1,213.3$ \\
\hline Stability signal (being a civil servant) & $0.069 * * *$ & 0.015 & 0.000 & & \\
\hline \multicolumn{6}{|c|}{ Neighborhoods with under 15\% Kanak residents (group 1) } \\
\hline Ethnic background signal (being Kanak) & $-0.114 * * *$ & 0.027 & 0.000 & 472 & 427.8 \\
\hline Stability signal (being a civil servant) & $0.054 * *$ & 0.025 & 0.033 & & \\
\hline \multicolumn{6}{|c|}{ Neighborhoods with $15 \%$ to $25 \%$ Kanak residents in Nouméa (group 2) } \\
\hline Ethnic background signal (being Kanak) & $-0.087 * * *$ & 0.023 & 0.000 & 624 & 551.0 \\
\hline Stability signal (being a civil servant) & $0.061 * * *$ & 0.022 & 0.006 & & \\
\hline \multicolumn{6}{|c|}{ Neighborhoods with over $25 \%$ Kanak residents in and outside Nouméa (group 3) } \\
\hline Ethnic background signal (being Kanak) & -0.038 & 0.034 & 0.264 & 272 & 262.8 \\
\hline Stability signal (being a civil servant) & $0.108 * * *$ & 0.036 & 0.003 & & \\
\hline
\end{tabular}

*** Significant at the 1\%, ** 5\%, *10\% threshold

Source: DALTON database 


\section{Conclusions}

This study draws upon the results of a discrimination test regarding access to private sector rental accommodation carried out between October 2015 and February 2016 in the Greater Nouméa area. The testing consisted of sending out responses to 342 ads on behalf of four applicants, i.e., 1,368 responses to real estate advertisements.

The objective of this test was to measure discrimination based on ethnic background by comparing the responses given to Kanak and to European rental housing-seekers. We added a financial stability signal indicating explicitly that the rental applicant was a civil servant in order to distinguish between discrimination based on background or ethnicity (preferences) and statistical discrimination (information). The latter may be associated with social precariousness which, as of June 2016, has become the $21^{\text {st }}$ legally prohibited ground for discrimination in French legislation.

We found that Kanak applicants are doubly penalized, first as a result of their less favorable, real or assumed, professional and financial situations, and, secondly, because of the ethnic preferences of the housing lessors. The latter are more marked when providers are individuals as opposed to real estate agencies.

The originality of this paper consists of underscoring the fact that discrimination on ethnic grounds varies depending on the neighborhood. In neighborhoods with a significant number of Kanak residents, social precariousness is the main obstacle to accessing housing for members of this ethnic community. However, a stable financial and occupational status increases the chances of finding rental housing for a Kanak applicant. The stability signal is an advantage in other neighborhoods, but to a lesser extent. Ethnic discrimination is concentrated in a smaller space: this is mostly in neighborhoods with the weakest representation of Kanaks and, to a lesser degree, in intermediate neighborhoods. Such discrimination is not statistically significant in areas with the highest number of Kanak residents.

These results suggest that discrimination regarding access to housing plays an active role in residential segregation in the Nouméa metropolitan area. Population distribution in the city depends both on residents' choices and provider, or real estate agency, offers. We have excluded residents' choice from the scope of this study, but we observe that provider offers play an active role in residential segregation in Nouméa.

The main limitation of this study is that its scope does not extend beyond the first step to finding housing, i.e., obtaining an appointment with the lessor. However, our findings are sufficiently robust to warrant a call for policy action. Whereas social diversity in neighborhoods is a stated government objective in France and in New Caledonia and despite the strict prohibition of discrimination on ethnic grounds, the finding that strong discrimination of this kind exists regarding access to housing in New Caledonia touches on important public policy issues. This study's findings are an invitation to serious reflection regarding the regulation of the real estate 
market and the means that may be implemented in order to counter housing discrimination. Public policy tools range from legislation to concrete measures aimed at giving teeth to the law. Actions to combat social precariousness, in particular through access to subsidized housing or financial security mechanisms aimed at providing guarantees to private lessors, should find a prominent place among these measures. 


\section{References}

Acolin, A., R. Bostic, and G. Painter. 2016. "A Field Study of Rental Market Discrimination Across Origins in France." Journal of Urban Economics 95, 49-63.

Ahmed, A., L. Andersson, and M. Hammarstedt. 2010. "Can Discrimination in the Housing Market be Reduced by Increasing the Information about the Applicants?" Land Economics 86, 79-90.

Ahmed, A., and M. Hammarstedt. 2008. "Discrimination in the Rental Housing Market: A Field Experiment on the Internet." Journal of Urban Economics 64, 362-72.

Arrow, K. J. 1973. "The Theory of Discrimination." In O. Ashenfelter and A. Rees (Eds.), Discrimination in Labor Markets. Princeton, NJ: Princeton University Press, 3-42

Baldini, M., and M. Federici. 2011. "Ethnic Discrimination in the Italian Rental Housing Market." Journal of Housing Economics 20, 1-14.

Bengtsson, R., E. Iverman, and B.T. Hinnerich. 2012. "Gender and Ethnic Discrimination in the Rental Housing Market." Applied Economics Letters 19, 1-5.

Bertrand, M., and E. Duflo. 2017. "Field Experiments on Discrimination.", in A. B. Banerjee and E. Duflo (Eds), Handbook of Economic Field Experiments, Vol.1, Chapter 8, North - Holland, 309-393.

Bonnet F., E. M. Lalé, M. Safi, and E. Wasmer. 2015. "Better Residential than Ethnic Discrimination! Reconciling Audit and Interview Findings in The Parisian Housing Market." Urbans Studies, 53, 2815-2833.

Bosch, M., A. Carnero, and L. Farre. 2010. "Information and Discrimination in the Rental Housing Market: Evidence from a Field Experiment." Regional Science and Urban Economics 40, 11-19.

Carlsson, M., and S. Eriksson. 2014. "Discrimination in the Rental Market for Apartments." Journal of Housing Economics 23, 41-54.

Carpusor, A., and W. Loges. 2006. "Rental Discrimination and Ethnicity in Names." Journal of Applied Social Psychology 36, 934-952.

Choi, S. J., J. Ondrich, and J. Yinger. 2005. "Do rental Agents Discriminate Against Minority Customers? Evidence from the 2000 Housing Discrimination Study." Journal of Housing Economics, 14, 1-26.

Datta, S. and V. Pathania. 2016. "For Whom Does The Phone (Not) Ring?: Discrimination In The Rental Housing Market In Delhi, India". 2016/55. Helsinki: UNU-WIDER.

Drydakis, N. 2011. "Ethnic Discrimination in the Greek Housing Market." Journal of Population Economics 24, 1235-1255.

Ewens, M., B. Tomlin, and L. C. Wang. 2014. "Statistical Discrimination or Prejudice? A Large Sample Field Experiment." Review of Economics and Statistics 96, 119-134.

Galster, G., H. MacDonald, and J. Nelson. 2016. "What Explains the Differential Treatment of Renters Based on Ethnicity? New Evidence from Sydney." Urban Affairs Review, November-232016, 1-30. 
Gorohouna, S., and C. Ris. 2013. "Decomposing Differences in Employment Outcomes Between Kanak and Other New Caledonians: How Important is the Role of School Achievement?" Australian Journal of Labour Economic 16, 115-135.

Hanson, A., and M. Santas. 2014 "Field Experiment Tests for Discrimination against Hispanics in the U.S. Rental Housing Market." Southern Economic Journal 81, 135-167.

Hanson, A., and Z. Hawley. 2011. "Do Landlords Discriminate in the Rental Housing Market? Evidence from an Internet Field Experiment in US Cities." Journal of Urban Economics 70, 99114.

Heckman J. J. 1998. “Detecting Discrimination.” Journal of Economic Perspectives 12, 101-116.

Heckman, J. J., and P. Siegelman. 1993. "The Urban Institute Audit Studies: Their Methods and Findings." In M. Fix, and R. Struyk (Eds.). Clear and Convincing Evidence: Measurement of Discrimination in America. Washington DC: Urban Institute Press, 187-258.

Heylen, K., and K. Van den Broeck. 2016. "Discrimination and Selection in the Belgian Private Rental Market." Housing Studies 31, 223-236.

Heylen, K., and K. Van den Broeck. 2015. "Differential Treatment of Rental Home Seekers According to their Sociodemographic and Economic Status by Real Estate Agencies in Belgium." European Journal of Homelessness 9, 39-62.

Institut d'Emission d'Outre-Mer. 2008. 'L'habitat et le développement urbain dans le Grand Nouméa: Constat \& Enjeux." Les Notes de l'Institut, 1-44.

Kain, J. 1968. "Housing Segregation, Negro Employment, and Metropolitan Decentralization." Quarterly Journal of Economics 82, 175-197.

Lichter, D., D. Parisi, and H. De Valk. 2017. "Residential Segregation." Pathways, Special Issue State of Union, The Poverty and Inequality Report 2016, 65-75.

Massey, D., and G. Lundy. 2001. "Use of Black English and Racial Discrimination in Urban Housing Markets: New Methods and Findings." Urban Affairs Review 36, 452-469.

Nelson, J., H. MacDonald, R. Dufty Jones, K. Dunn, and Y. Paradies. 2015. "Ethnic Discrimination in Private Rental Housing Markets in Australia." In R. Dufty Jones and D. Rogers (Eds). Housing in Twenty-First Century Australia: People, Practices and Policies, Ashgate, Farnhman, 39-56.

Oh, S. J., and J. Yinger. 2015. "What Have We Learned from Paired Testing in Housing Markets?", Cityscape: a Journal of Policy Developpement and Research, 17 (3), 15-59,

Ondrich, J., S. L. Ross, and J. Yinger. 2001. "Geography of Housing Discrimination.” Journal of Housing Research 12, 217- 239.

Ondrich, J., S. L. Ross, J. Yinger. 2003. "Now You See It, Now You Don't: Why Do Real Estate Agents Withhold Available Houses From Black Customers?" Review of Economics and Statistics $85,854-73$.

Page, M. 1995. "Racial and Ethnic Discrimination in Urban Housing Markets: Evidence from a Recent Audit Study." Journal of Urban Economics 38, 183-206. 
Pestana, G., O. Hoffer, P-C, Pantz, and V. Clément. 2014. "Kanak and the City: Being of the Place, Expressing It, Urban Issues." PIURN Conference, Nov. 2014, University of New Caledonia.

Roychoudhury, C., and A. Goodman. 1996. "Evidence of Racial Discrimination in Different Dimension of Owner-Occupied Housing Search." Real Estate Economics, 24, 161-178.

Thorat, S., A. Banerjee, V.K. Mishra, and F. Rizvi. 2015. "Urban Rental Housing Market Caste and Religion Matters in Access." Economic and Political Weekly 50, 47-54.

Yinger, J. 1986. "Measuring Racial Discrimination With Fair Housing Audits: Caught In The Act.” American Economic Review 76, 881-893.

Zhao, B. 2005. "Does the Number Of Houses A Broker Shows Depend On A Homeseeker's Race?” Journal of Urban Economics 57, 128-47.

Zhao, B., J. Ondrich, and J. Yinger. 2006. Why Do Real Estate Brokers Continue To Discriminate?" Journal of Urban Economics 59, 394-419. 


\section{Annex 1}

Table A1: Summary of principal works on discrimination in the housing market, where ethnic composition of the neighborhood is directly or indirectly insinuated

\begin{tabular}{|c|c|c|c|c|}
\hline Authors & $\begin{array}{c}\text { Method } \\
\text { Output }\end{array}$ & Location & $\begin{array}{l}\text { Weight of minority in } \\
\text { total population (1) }\end{array}$ & Estimated effect \\
\hline \multicolumn{5}{|l|}{ United States } \\
\hline $\begin{array}{l}\text { Yinger (1986) } \\
\text { AER }\end{array}$ & $\begin{array}{l}\text { Audit } \\
\text { Number of homes } \\
\text { presented to } \\
\text { Black/White } \\
\text { applicants }\end{array}$ & $\begin{array}{l}\text { United States } \\
\text { Boston } \\
312 \text { offers in } 1981\end{array}$ & $25 \%$ & $\begin{array}{l}\text { Discrimination against Blacks } \\
\text { and Hispanics is very } \\
\text { significant in neighborhoods } \\
\text { dominated by Whites ( }-30 \%) \text {. It } \\
\text { is practically absent in less } \\
\text { segregated neighborhoods. }\end{array}$ \\
\hline Pager (1995) JUE & $\begin{array}{l}\text { Audit } \\
\text { Number of homes } \\
\text { presented to a } \\
\text { Hispanic and Black } \\
\text { applicant }\end{array}$ & $\begin{array}{l}\text { United States } \\
25 \text { American cities } \\
3,500 \text { offers for } \\
\text { rentals and for sales } \\
\text { in the first half of } \\
1989\end{array}$ & $\begin{array}{l}\text { At least } 12 \% \text { Black and } \\
7 \% \text { or more Hispanic } \\
\text { Analysis of a threshold } \\
\text { effect with a } \\
\text { neighborhood } \\
\text { concentration of at least } \\
20 \% \text { Black or Hispanic }\end{array}$ & $\begin{array}{l}\text { Discrimination varies between - } \\
10 \% \text { and }-30 \% \text { depending on } \\
\text { the area. } \\
\text { The ethnic environment } \\
\text { significantly affects } \\
\text { discrimination for sales but not } \\
\text { for rentals. }\end{array}$ \\
\hline $\begin{array}{l}\text { Roychoudhury } \\
\text { and Goodman } \\
\text { (1996) REE }\end{array}$ & $\begin{array}{l}\text { Audit } \\
\text { Black/White } \\
\text { applicant }\end{array}$ & $\begin{array}{l}\text { United States } \\
\text { Detroit } \\
319 \text { tests from } 1980 \\
\text { to } 1990\end{array}$ & $\begin{array}{l}\text { Two types of } \\
\text { neighborhoods, one } \\
60 \% \text { or more Black and } \\
\text { one less than } 60 \% \\
\text { Black (on average, } 80 \% \\
\text { of Detroit's population } \\
\text { is Black) }\end{array}$ & $\begin{array}{l}\text { Discrimination is lower by } \\
\text { black real estate agents and in } \\
\text { neighborhoods with a higher } \\
\text { proportion of Blacks. }\end{array}$ \\
\hline $\begin{array}{l}\text { Ondrich et al. } \\
\text { (2003) RES }\end{array}$ & $\begin{array}{l}\text { Audit } \\
\text { Black/White } \\
\text { applicant } \\
\text { Hispanic/White } \\
\text { applicant }\end{array}$ & $\begin{array}{l}\text { United States } \\
25 \text { American cities } \\
2,465 \text { offers for } \\
\text { rentals and for sales } \\
\text { from May to August } \\
1989\end{array}$ & $\begin{array}{l}\text { At least } 12 \% \text { Black and } \\
7 \% \text { or more Hispanic }\end{array}$ & $\begin{array}{l}\text { Discrimination is lower for } \\
\text { properties located in areas } \\
\text { where Blacks are over- } \\
\text { represented. }\end{array}$ \\
\hline $\begin{array}{l}\text { Carpusor and } \\
\text { Loges (2006) } \\
\text { JASP }\end{array}$ & $\begin{array}{l}\text { Random testing using } \\
\text {-name } \\
\text {-email } \\
\text { Afro-American / } \\
\text { Arab /white }\end{array}$ & $\begin{array}{l}\text { United States } \\
\text { Los Angeles } \\
1,100 \text { offers in } \\
\text { March } 2003\end{array}$ & $\begin{array}{l}9.8 \% \text { Afro Americans, } \\
0.7 \% \text { Arab, } 48.7 \% \\
\text { white }\end{array}$ & $\begin{array}{l}\text { Deviation of } 23 \text { (Arabs) and } 33 \\
\text { percentage points (Blacks) in } \\
\text { responses. } \\
\text { No analysis on the effect of the } \\
\text { ethnic environment. }\end{array}$ \\
\hline $\begin{array}{l}\text { Hanson and } \\
\text { Santas (2014) } \\
\text { SEJ }\end{array}$ & $\begin{array}{l}\text { Testing } \\
\text { Matching } \\
\text { Assimilated } \\
\text { Hispanics and less } \\
\text { assimilated } \\
\text { immigrants (level of } \\
\text { English) }\end{array}$ & $\begin{array}{l}\text { United States } \\
21 \text { American cities } \\
\text { 3,072 offers }\end{array}$ & $\begin{array}{l}\text { Cities between } 3 \% \text { and } \\
44 \% \text { Hispanic }\end{array}$ & $\begin{array}{l}\text { 5-point deviation in the } \\
\text { southwest and not significant } \\
\text { elsewhere. Not directly related } \\
\text { to the \% of Hispanics in the } \\
\text { area. }\end{array}$ \\
\hline $\begin{array}{l}\text { Hanson and } \\
\text { Hawley (2011 and } \\
\text { 2014) JUE and } \\
\text { RSUE }\end{array}$ & $\begin{array}{l}\text { Testing } \\
\text { Matching } \\
\text { Africans using their } \\
\text { name }\end{array}$ & $\begin{array}{l}\text { United States } \\
\text { Atlanta, Boston, } \\
\text { Chicago, Dallas, } \\
\text { Washington, D.C, } \\
\text { Houston, Los } \\
\text { Angeles, New York, } \\
\text { Seattle, and San } \\
\text { Francisco local } \\
\text { July to October } 2009 \\
\text { 2,010 offers tested }\end{array}$ & $\begin{array}{l}\text { Variation from } 0 \% \text { to } \\
100 \% \text { depending on the } \\
\text { neighborhood }\end{array}$ & $\begin{array}{l}\text { Deviation of } 5 \text { percentage } \\
\text { points. Stronger discrimination } \\
\text { in mixed neighborhoods. }\end{array}$ \\
\hline $\begin{array}{l}\text { Ewens et al. } \\
\text { (2014) RES }\end{array}$ & $\begin{array}{l}\text { Random testing using } \\
\text { Africans using their } \\
\text { name }\end{array}$ & $\begin{array}{l}\text { United States } \\
34 \text { cities } \\
14,237 \text { offers tested }\end{array}$ & $\begin{array}{l}\text { Variation from } 0 \% \text { to } \\
100 \% \text { depending on the } \\
\text { neighborhood }\end{array}$ & $\begin{array}{l}\text { Deviation of } 5 \text { percentage } \\
\text { points. Lack of linear relation } \\
\text { between } \% \text { of Blacks in the area } \\
\text { and racial discrimination. }\end{array}$ \\
\hline
\end{tabular}




\begin{tabular}{|c|c|c|c|c|}
\hline Authors & $\begin{array}{c}\text { Method } \\
\text { Output }\end{array}$ & Location & $\begin{array}{l}\text { Weight of minority in } \\
\text { total population (1) }\end{array}$ & Estimated effect \\
\hline \multicolumn{5}{|l|}{ Europe } \\
\hline $\begin{array}{l}\text { Acolin, Bostic, } \\
\text { and Painter } \\
\text { (2016) JUE }\end{array}$ & $\begin{array}{l}\text { Testing using name } \\
\text { and e-mail, through } \\
\text { the leading internet } \\
\text { platform, } \\
6 \text { applicants } \\
\text { French, Northern } \\
\text { Africa, } \\
\text { Sub-Saharan Africa, } \\
\text { Southern European } \\
\text { (Portugal-Spain), } \\
\text { Eastern European } \\
\text { (Poland) and Turkey }\end{array}$ & $\begin{array}{l}\text { France, April to May } 2014 \\
300 \text { offers leading to } 1800 \\
\text { observations }\end{array}$ & $\begin{array}{l}\text { Share of immigrants or } \\
\text { second generations } \\
\text { ranges from } 8,4 \% \text { in the } \\
\text { Northwest to } 35,4 \% \text { in } \\
\text { Paris Region. }\end{array}$ & $\begin{array}{l}\text { Applicants with foreign } \\
\text { sounding names are } 16 \text { to } \\
22 \text { percentage points } \\
\text { below applicants with } \\
\text { French names. } \\
\text { The level of } \\
\text { discrimination is largest } \\
\text { in Northeast France, } \\
\text { Southeast France, and in } \\
\text { Paris and its high-income } \\
\text { western suburbs. }\end{array}$ \\
\hline $\begin{array}{l}\text { Bonnet, Lalé, } \\
\text { Safi, and Wasmer } \\
(2015)\end{array}$ & $\begin{array}{l}\text { Testing by telephone } \\
4 \text { applicants } \\
\text { combining two } \\
\text { names (French vs } \\
\text { North African origin) } \\
\text { and two locations } \\
\text { (rich suburbs vs } \\
\text { deprived } \\
\text { neighborhood). }\end{array}$ & $\begin{array}{l}\text { France, March to April } \\
2009 \\
250 \text { offers }\end{array}$ & $\begin{array}{l}\text { The percentage of } \\
\text { immigrants from North } \\
\text { Africa is } 5.2 \% \text { in the } \\
\text { Paris region. }\end{array}$ & $\begin{array}{l}\text { North African origin has } \\
\text { no significant } \\
\text { discriminatory effect } \\
\text { when applicants first } \\
\text { indicate living in a } \\
\text { deprived suburb. }\end{array}$ \\
\hline $\begin{array}{l}\text { Ahmed and } \\
\text { Hammarstedt } \\
\text { (2008) JUE }\end{array}$ & $\begin{array}{l}\text { Testing using name } \\
\text { Matching using } \\
\text { email } \\
3 \text { applicants: } \\
\text { Swedish man } \\
\text { Swedish woman } \\
\text { Arab/Muslim man }\end{array}$ & $\begin{array}{l}\text { Sweden } \\
500 \text { in February to March } \\
2007\end{array}$ & $\begin{array}{l}\text { Percentage of Arab or } \\
\text { Muslim foreigners in the } \\
\text { population as a whole } \\
12 \% \times 14 \%=1.7 \%\end{array}$ & $\begin{array}{l}\text { Scale of discrimination } \\
\text { varies between } 25-35 \\
\text { percentage points. } \\
\text { No analysis on the effect } \\
\text { of the ethnic } \\
\text { environment. }\end{array}$ \\
\hline $\begin{array}{l}\text { Bengtsson et al. } \\
\text { (2012) AEL }\end{array}$ & $\begin{array}{l}\text { Testing using email } \\
\text { Swedish man } \\
\text { Swedish woman } \\
\text { Arab/Muslim man }\end{array}$ & $\begin{array}{l}\text { Sweden } \\
\text { Greater Stockholm area } \\
1,213 \text { observations } \\
\text { between March and May } \\
2010\end{array}$ & $\begin{array}{l}18 \% \text { immigrants in } \\
\text { downtown area versus } \\
25 \% \text { in the suburbs and } \\
\text { other cities of the } \\
\text { Greater Stockholm area }\end{array}$ & $\begin{array}{l}\text { Deviation of } 6 \\
\text { percentage points for } \\
\text { women and no difference } \\
\text { for men. Non-significant } \\
\text { effect in downtown area } \\
\text { where proportion of } \\
\text { immigrants is smaller. }\end{array}$ \\
\hline $\begin{array}{l}\text { Carlsson and } \\
\text { Eriksson (2014) } \\
\text { JHE }\end{array}$ & $\begin{array}{l}\text { Random testing } \\
\text { Swedish man } \\
\text { Swedish woman } \\
\text { Muslim man } \\
\text { Muslim woman }\end{array}$ & $\begin{array}{l}\text { Sweden } \\
5827 \text { rental offers from } \\
\text { October } 2010 \text { to March } \\
2011\end{array}$ & $\begin{array}{l}10 \% \text { EU foreigners and } \\
10 \% \text { foreigners from } \\
\text { outside of the EU }\end{array}$ & $\begin{array}{l}\text { Discrimination varies } \\
\text { between } 14 \text { to } 10 \\
\text { percentage points. } \\
\text { Discrimination is } \\
\text { stronger against Muslims } \\
\text { outside of Stockholm. }\end{array}$ \\
\hline $\begin{array}{l}\text { Baldini and } \\
\text { Federici (2011) } \\
\text { JHE }\end{array}$ & $\begin{array}{l}\text { Random testing } \\
\text { Men/women/Muslim } \\
\text { or from Eastern } \\
\text { Europe } \\
\text { Positive signal for the } \\
\text { person }\end{array}$ & $\begin{array}{l}\text { Italy } \\
41 \text { Italian cities } \\
3,676 \text { offers in March and } \\
\text { July } 2010\end{array}$ & $\begin{array}{l}9.5 \% \text { of total residents in } \\
\text { northern regions, } 9 \% \text { in } \\
\text { the center and only } 2.6 \% \\
\text { in the south }\end{array}$ & $\begin{array}{l}\text { 20-point deviation } \\
\text { Significant effect only in } \\
\text { northern regions where } \\
\text { foreigners are over- } \\
\text { represented. }\end{array}$ \\
\hline $\begin{array}{l}\text { Drydakis (2011) } \\
\text { JPE }\end{array}$ & $\begin{array}{l}\text { Testing by telephone } \\
\text { Albanian woman and } \\
\text { Greek woman } \\
\text { Name and } \\
\text { pronunciation of } \\
\text { words }\end{array}$ & $\begin{array}{l}\text { Greece } \\
\text { Athens } \\
122 \text { neighborhoods } \\
4,351 \text { offers in November } \\
2006 \text { and October } 2007\end{array}$ & $4 \%$ for all of Greece & $\begin{array}{l}\text { Deviation between } 25 \% \\
\text { and } 46 \% \text {. } \\
\text { Discrimination is } \\
\text { stronger in wealthier } \\
\text { neighborhoods. }\end{array}$ \\
\hline $\begin{array}{l}\text { Bosch, Carnero } \\
\text { and Farré (2010) } \\
\text { RSUE }\end{array}$ & $\begin{array}{l}\text { Testing by email } \\
\text { Matching in pairs } \\
\text { Moroccan and } \\
\text { Spanish applicant } \\
\text { Quality of applicant }\end{array}$ & $\begin{array}{l}\text { Spain's } 20 \text { biggest cities } \\
1,809 \text { rental offers } \\
\text { between January and } \\
\text { March } 2009\end{array}$ & $\begin{array}{l}1.5 \% \text { Moroccan } \\
\text { emigrants }\end{array}$ & $\begin{array}{l}\text { Deviation of } 10 \\
\text { percentage points. } \\
\text { Larger deviation for men } \\
\text { than for women. } \\
\text { No analysis on the effect. }\end{array}$ \\
\hline
\end{tabular}




\begin{tabular}{|c|c|c|c|c|}
\hline & $\begin{array}{l}\text { indicated by their } \\
\text { profession }\end{array}$ & & & $\begin{array}{l}\text { of the ethnic } \\
\text { environment. }\end{array}$ \\
\hline $\begin{array}{l}\text { Heylen, Van den } \\
\text { Broeck (2016) HS }\end{array}$ & $\begin{array}{l}\text { Testing by email } \\
\text { Matching and by } \\
\text { telephone contact } \\
\text { Moroccan and } \\
\text { Turkish }\end{array}$ & $\begin{array}{l}\text { Belgium } \\
1,769 \text { (e-mail)+ } 684 \\
\text { (telephone) offers }\end{array}$ & $\begin{array}{l}11 \% \text { Moroccan and } \\
\text { Turkish foreigners } \\
\text { representing } 7 \% \text { and } 3 \% \\
\text { of the foreign population }\end{array}$ & $\begin{array}{l}\text { Positive effect for email } \\
\text { applications but not for } \\
\text { telephone applications. } \\
\text { No analysis on the effect } \\
\text { of the ethnic } \\
\text { environment. }\end{array}$ \\
\hline $\begin{array}{l}\text { Heylen, Van den } \\
\text { Broeck (2015) } \\
\text { EJH }\end{array}$ & $\begin{array}{l}\text { Telephone contact } \\
\text { test } \\
\text { Unemployed } \\
\text { individuals and } \\
\text { foreigners }\end{array}$ & $\begin{array}{l}\text { Belgium } \\
900 \text { real estate agencies } \\
\text { are tested } \\
\text { June } 2013\end{array}$ & $\begin{array}{l}8.5 \% \text { unemployed } \\
\text { population and } 11 \% \\
\text { foreigners }\end{array}$ & $\begin{array}{l}41 \% \text { claim being able to } \\
\text { avoid foreigners and } \\
60 \% \text { say the same for } \\
\text { unemployed individuals. } \\
\text { No analysis on the effect } \\
\text { of the ethnic } \\
\text { environment. }\end{array}$ \\
\hline \multicolumn{5}{|l|}{ Others } \\
\hline $\begin{array}{l}\text { Nelson et al. } \\
\text { (2015) } \\
\text { Galster et al. } \\
\text { (2016) UAR }\end{array}$ & $\begin{array}{l}\text { Audit matching in } \\
\text { pairs } \\
\text { Anglo - Indian - } \\
\text { Muslim/ Middle- } \\
\text { eastern }\end{array}$ & $\begin{array}{l}\text { Australia } \\
369 \text { to } 537 \text { offers in the } \\
\text { greater Sydney area } \\
\text { between August and } \\
\text { November } 2013\end{array}$ & $\begin{array}{l}2 \% \text { Indians and } 4.4 \% \\
\text { Muslims }\end{array}$ & $\begin{array}{l}\text { Significant differences in } \\
\text { the information } \\
\text { transmitted. The effect of } \\
\text { the ethnic environment is } \\
\text { pooled with others } \\
\text { variables. }\end{array}$ \\
\hline $\begin{array}{l}\text { Datta and } \\
\text { Pathania (2016) }\end{array}$ & $\begin{array}{l}\text { Random testing- } \\
\text { Using name } \\
\text { Email } \\
\text { Hindu vs. Muslim }\end{array}$ & $\begin{array}{l}\text { Delhi India } \\
171 \text { rental offers in the } \\
\text { summer of } 2015\end{array}$ & 13\% Muslims & $\begin{array}{l}-12 \% \text { penalty against } \\
\text { Muslims. No analysis on } \\
\text { the effect of the ethnic } \\
\text { environment. }\end{array}$ \\
\hline
\end{tabular}

(1) Data in article or census data

Table A2. Characteristics of neighborhood groups

\begin{tabular}{|l|c|c|c|c|c|c|}
\hline & $\begin{array}{c}\text { \% of housing } \\
\text { in Greater } \\
\text { Nouméa }\end{array}$ & $\begin{array}{c}\text { \% of the } \\
\text { population } \\
\text { in Greater } \\
\text { Nouméa }\end{array}$ & $\begin{array}{c}\% \text { owners } \\
\text { (2014) }\end{array}$ & $\begin{array}{c}\text { \% social } \\
\text { housing } \\
\text { (2014) }\end{array}$ & $\begin{array}{c}\% \text { private } \\
\text { rental } \\
\text { housing } \\
(2014)\end{array}$ & $\begin{array}{c}\% \text { of } \\
\text { Kanak } \\
(2009)\end{array}$ \\
\hline Neighborhoods less than 15\% Kanak (group 1) & $35 \%$ & $29 \%$ & $49 \%$ & $13 \%$ & $38 \%$ & $10 \%$ \\
\hline $\begin{array}{l}\text { Neighborhoods 15\% to 25\% Kanak in Nouméa } \\
\text { (group 2) }\end{array}$ & $12 \%$ & $11 \%$ & $43 \%$ & $35 \%$ & $21 \%$ & $25 \%$ \\
\hline $\begin{array}{l}\text { Neighborhoods more than 25\% Kanak in Nouméa } \\
\text { and outside of Nouméa (group 3) }\end{array}$ & $53 \%$ & $60 \%$ & $62 \%$ & $22 \%$ & $15 \%$ & $30 \%$ \\
\hline
\end{tabular}

Note: These statistics include all neighborhoods of the Greater Nouméa agglomeration, whether tested or not.

Sources: 2014 census data (ISEE), Pestana et al. (2014) 
Table A3: Characteristics of offers

\begin{tabular}{|c|c|c|}
\hline & In $\%$ of offers & $\begin{array}{c}\text { Positive response rate } \\
\text { Per offer }\end{array}$ \\
\hline \multicolumn{3}{|l|}{ Characteristics of the offer and the company } \\
\hline \multicolumn{3}{|l|}{ Size of apartments } \\
\hline F1 & $15.5 \%$ & $66.0 \%$ \\
\hline F2-LOFT & $38.6 \%$ & $74.2 \%$ \\
\hline F3 & $30.1 \%$ & $81.6 \%$ \\
\hline F4-F5 & $15.8 \%$ & $75.9 \%$ \\
\hline \multicolumn{3}{|l|}{ Characteristics of lessor } \\
\hline Woman & $49.2 \%$ & $78.9 \%$ \\
\hline \multicolumn{3}{|l|}{ Type of lessor } \\
\hline Agencies & $19.3 \%$ & $83.3 \%$ \\
\hline Individuals & $80.7 \%$ & $73.6 \%$ \\
\hline \multicolumn{3}{|l|}{ Location of offers } \\
\hline Less than $15 \%$ (group 1) & $34.5 \%$ & $76.3 \%$ \\
\hline Between $15 \%$ and $25 \%$ in Nouméa (group 2) & $45.6 \%$ & $74.4 \%$ \\
\hline More than $25 \%$ and outside of Nouméa (group 3) & $19.9 \%$ & $76.5 \%$ \\
\hline \multicolumn{3}{|l|}{ Average price per $m^{2}$} \\
\hline $\begin{array}{c}\text { CFP franc average } \\
\text { (standard deviation) }\end{array}$ & $2,165.2(549.7)$ & - \\
\hline \multicolumn{3}{|l|}{ Type of game } \\
\hline A & $55.9 \%$ & $75.9 \%$ \\
\hline B & $44.2 \%$ & $74.8 \%$ \\
\hline TOTAL & $100 \%$ & $75.4 \%$ \\
\hline Number of observations & \multicolumn{2}{|c|}{342} \\
\hline
\end{tabular}

Source: DALTON database 
Table A4: Status and work situation of men of Kanak or European backgrounds living in the south province

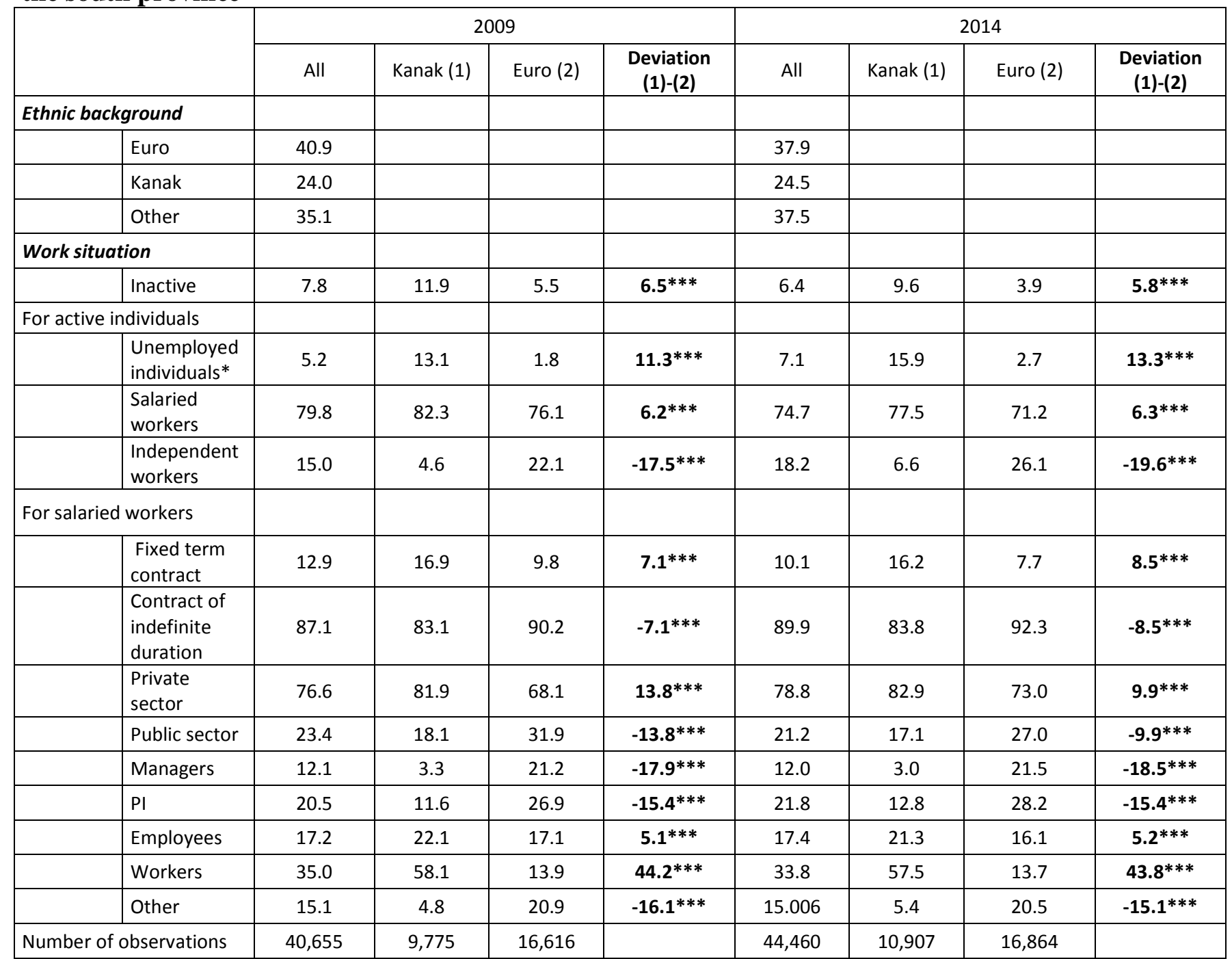

Chi square test $* * *$ at the threshold limit of $1 \%, * * 5 \%, *$ and $10 \%$

(1) Unemployed in terms of the census

Chosen field: men aged 25-55 from the south province

Source: Data from 2009 and 2014 census, ISEE. 


\section{Annex 2}

Table A4: Ethnic signal effect (without stability signal) in three neighborhood groups

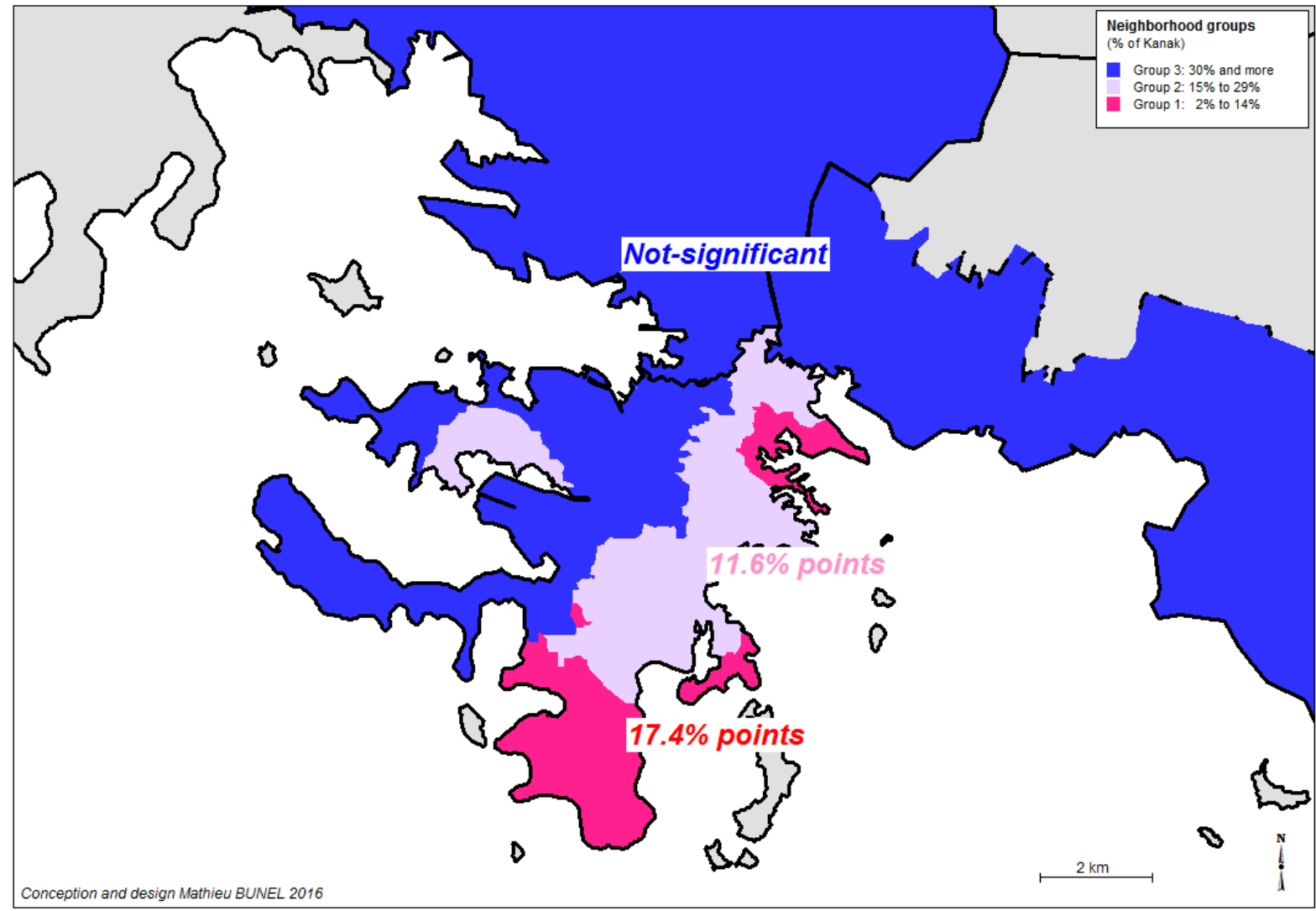

Note: Group 3 includes the areas of Païta, Dumbéa and Mont Dore even though the proportion of Kanaks is less than $30 \%$ in some of these neighborhoods 
18-5. Evaluating the impact of firm tax credits. Results from the French natural experiment CICE

Fabrice Gilles, Yannick L'Horty, Ferhat Mihoubi, Xi Yang

18-4. Impact of type 2 diabetes on health expenditure: an estimation based on individual administrative data

François-Olivier Baudot, Anne-Sophie Aguadé,Thomas Barnay, Christelle Gastaldi-

Ménager, Anne Fargot-Campagna

18-3. How does labour market history influence the access to hiring interviews?

Emmanuel Duguet, Rémi Le Gall, Yannick L'Horty, Pascale Petit

18-2. Occupational mobility and vocational training over the life cycle

Anthony Terriau

18-1. Retired, at last? The short-term impact of retirement on health status in France Thomas Barnay, Eric Defebvre 
17-11. Hiring discrimination against women: distinguishing taste based discrimination from statistical discrimination

Emmanuel Duguet, Loïc du Parquet, Pascale Petit

17-10. Pension reforms, older workers' employment and the role of job separation and finding rates in France

Sarah Le Duigou, Pierre-Jean Messe

17-9. Healthier when retiring earlier? Evidence from France

Pierre-Jean Messe, François-Charles Wolff

17-8. Revisting Hopenhayn and Nicolini's optimal unemployment insurance with job search monitoring and sanctions

Sebastien Menard, Solenne Tanguy

17-7. Ethnic Gaps in Educational Attainment and Labor-Market Outcomes: Evidence from France

Gabin Langevin, David Masclet, Fabien Moizeau, Emmanuel Peterle

17-6. Identifying preference-based discrimination in rental market: a field experiment in Paris

Mathieu Bunel, Yannick L’Horty, Loïc du Parquet, Pascale Petit

17-5. Chosen or Imposed? The location strategies of households

Emilie Arnoult, Florent Sari

17-4. Optimal income taxation with composition effects

Laurence Jacquet, Etienne Lehmann

17-3. Labor Market Effects of Urban Riots: an experimental assessment

Emmanuel Duguet, David Gray, Yannick L'Horty, Loic du Parquet, Pascale Petit

17-2. Does practicing literacy skills improve academic performance in first-year university students? Results from a randomized experiment

Estelle Bellity, Fabrices Gilles, Yannick L'Horty

17-1. Raising the take-up of social assistance benefits through a simple mailing: evidence from a French field experiment

Sylvain Chareyron, David Gray, Yannick L'Horty 
16-8. Endogenous wage rigidities, human capital accumulation and growth Ahmed Tritah

16-7. Harder, better, faster...yet stronger? Working conditions and self-declaration of chronic diseases

Eric Defebvre

16-6. The influence of mental health on job retention

Thomas Barnay, Eric Defebvre

16-5. The effects of breast cancer on individual labour market outcomes: an evaluation from an administrative panel

Thomas Barnay, Mohamed Ali Ben Halima, Emmanuel Duguet, Christine Le Clainche, Camille Regaert

16-4. Expectations, Loss Aversion, and Retirement Decisions in the Context of the 2009 Crisis in Europe

Nicolas Sirven, Thomas Barnay

16-3. How do product and labor market regulations affect aggregate employment, inequalities and job polarization? A general equilibrium approach

Julien Albertini, Jean-Olivier Hairault, François Langot, Thepthida Sopraseuth

16-2. Acces to employment with age and gender: results of a controlled experiment Laetitia Challe, Florent Fremigacci, François Langot, Yannick L'Horty, Loïc Du Parquet, Pascale Petit

16-1. An evaluation of the 1987 French Disabled Workers Act: Better paying than hiring

Thomas Barnay, Emmanuel Duguet, Christine Le Clainche, Yann Videau 
15-10. Optimal Income Taxation with Unemployment and Wage Responses: A Sufficient Statistics Approach

Kory Kroft, Kavan Kucko, Etienne Lehmann, Johannes Schmieder

15-9. Search frictions and (in) efficient vocational training over the life-cycle Arnaud Chéron, Anthony Terriau

15-8. Absenteeism and productivity: the experience rating applied to employer contributions to health insurance

Sébastien Ménard, Coralia Quintero Rojas

15-7. Take up of social assistance benefits: the case of homeless Sylvain Chareyron

15-6. Spatial mismatch through local public employment agencies. Answers from a French quasi-experiment

Mathieu Bunel, Elisabeth Tovar

15-5. Transmission of vocational skills at the end of career: horizon effect and technological or organisational change

Nathalie Greenan, Pierre-Jean Messe

15-4. Protecting biodiversity by developing bio-jobs: A multi-branch analysis with an application on French data

Jean De Beir, Céline Emond, Yannick L'Horty, Laetitia Tuffery

15-3. Profit-Sharing and Wages: An Empirical Analysis Using French Data Between 2000 and 2007

Noélie Delahaie, Richard Duhautois

15_2. A meta-regression analysis on intergenerational transmission of education: publication bias and genuine empirical effect

Nicolas Fleury, Fabrice Gilles

15_1. Why are there so many long-term unemployed in Paris?

Yannick L'Horty, Florent Sari 
14-14. Hiring discrimination based on national origin and the competition between employed and unemployed job seekers

Guillaume Pierné

14-13. Discrimination in Hiring: The curse of motorcycle women

Loïc Du Parquet, Emmanuel Duguet, Yannick L'Horty, Pascale Petit

14-12. Residential discrimination and the ethnic origin: An experimental assessment in the Paris suburbs

Emmanuel Duguet, Yannick L'Horty, Pascale Petit

14-11. Discrimination based on place of residence and access to employment Mathieu Bunel, Yannick L'Horty, Pascale Petit

14-10. Rural Electrification and Household Labor Supply: Evidence from Nigeria Claire Salmon, Jeremy Tanguy

14-9. Effects of immigration in frictional labor markets: theory and empirical evidence from EU countries

Eva Moreno-Galbis, Ahmed Tritah

14-8. Health, Work and Working Conditions: A Review of the European Economic Literature

Thomas Barnay

14-7. Labour mobility and the informal sector in Algeria: a cross-sectional comparison (2007-2012)

Philippe Adair, Youghourta Bellache

14-6. Does care to dependent elderly people living at home increase their mental health? Thomas Barnay, Sandrine Juin

14_5. The Effect of Non-Work Related Health Events on Career Outcomes: An Evaluation in the French Labor Market

Emmanuel Duguet, Christine le Clainche

14_4. Retirement intentions in the presence of technological change: Theory and evidence from France

Pierre-Jean Messe, Eva Moreno - Galbis, Francois-Charles Wolff

14_3. Why is Old Workers' Labor Market more Volatile? Unemployment Fluctuations over the Life-Cycle

Jean-Olivier Hairault, François Langot, Thepthida Sopraseuth

14_2. Participation, Recruitment Selection, and the Minimum Wage

Frédéric Gavrel

14_1. Disparities in taking sick leave between sectors of activity in France: a longitudinal analysis of administrative data

Thomas Barnay, Sandrine Juin, Renaud Legal 
13_9. An evaluation of the impact of industrial restructuring on individual human capital accumulation in France (1956-1993)

Nicolas Fleury, Fabrice Gilles

13_8. On the value of partial commitment for cooperative investment in buyer-supplier relationship

José de Sousa, Xavier Fairise

13-7. Search frictions, real wage rigidities and the optimal design of unemployment insurance

Julien Albertini, Xavier Fairise

13-6. Tax me if you can! Optimal non linear income tax between competing governments Etienne Lehmann, Laurent Simula, Alain Trannoy

13-5. Beyond the labour income tax wedge: The unemployment-reducing effect of tax progressivity

Etienne Lehmann, Claudio Lucifora, Simone Moriconi, Bruno Van Der Linden

13-4. Discrimination based on place of residence and access to employment

Mathieu Bunel, Emilia Ene Jones, Yannick L'Horty, Pascale Petit

12-3. The determinants of job access channels: evidence from the youth labor market in Franc

Jihan Ghrairi

13-2. Capital mobility, search unemployment and labor market policies: The case of minimum wages

Frédéric Gavrel

13-1. Effort and monetary incentives in Nonprofit et For-Profit Organizations Joseph Lanfranchi, Mathieu Narcy 
The CNRS Institute for Labor Studies and Public Policies (the TEPP Institute, FR n ${ }^{\circ} 3435$ CNRS) gathers together research centres specializing in economics and sociology:

- L'Equipe de Recherche sur l'Utilisation des Données Individuelles en lien avec la Théorie Economique (Research Team on Use of Individuals Data in connection with economic theory), ERUDITE, University of Paris-Est Créteil and University of ParisEst Marne-la-Vallée

- Le Centre d'Etudes des Politiques Economiques de l'université d'Evry (Research Centre focused on the analysis of economic policy and its foundations and implications), EPEE, University of Evry Val d'Essonne

- Le Centre Pierre Naville (Research on Work and Urban Policies), CPN, University of Evry Val d'Essonne

- Le Groupe d'Analyse des Itinéraires et des Niveaux Salariaux (Group on Analysis of Wage Levels and Trajectories), GAINS, University of the Maine

- Le Centre de Recherches en Economie et en Management, (Research centre in Economics and Management), CREM, University of Rennes 1 et University of Caen Basse-Normandie

- Le Groupe de Recherche ANgevin en Économie et Management (Angevin Research Group in Economics and Management), GRANEM, University of Angers ;

- Le Centre de Recherche en Economie et Droit (Research centre in Economics and Law) CRED, University of Paris II Panthéon-Assas ;

- Le Laboratoire d'Economie et de Management Nantes-Atlantique (Laboratory of Economics and Management of Nantes-Atlantique) LEMNA, University of Nantes ;

- Le Laboratoire interdisciplinaire d'étude du politique Hannah Arendt - Paris Est, LIPHA-PE

- Le Centre d'Economie et de Management de l'Océan Indien, «CEMOI», équipe d'accueil $n^{\circ} E A 13$, rattachée à l'Université de la Réunion

The TEPP Institute brings together 200 researchers and research professors and $140 \mathrm{PhD}$ students who study changes in work and employment in relation to the choices made by firms and analyse public policies using new evaluation methods. 